原著

\title{
エナメル質表層フッ素浱度とエナメル質溶假性の 函面，部位および年㳡命群別の研究*
}

\author{
石 井拓 男**
}

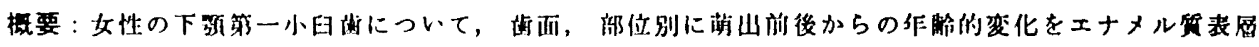

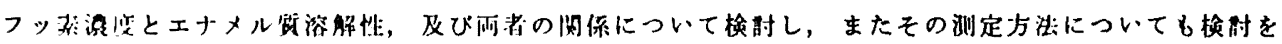
行った。結果の琏姴は次のようであった。

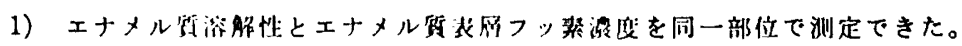

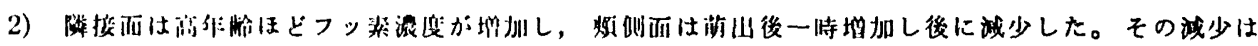

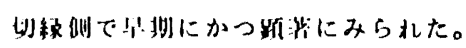

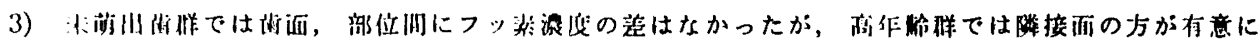

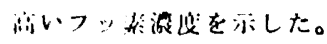

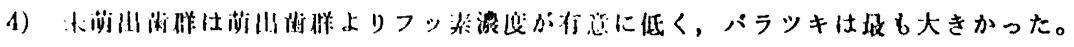

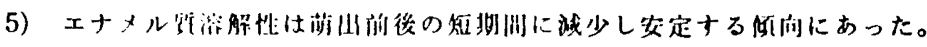

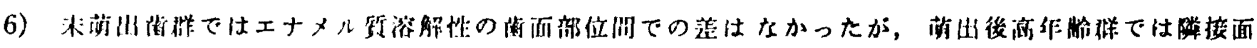
のうが颀叫洏より低くなった。

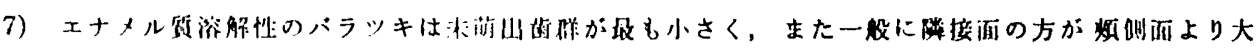
きがた。

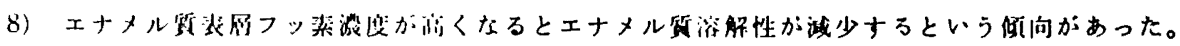

\section{緒言}

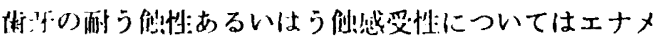

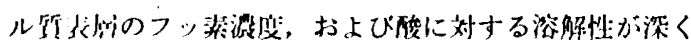
かかれりあっていることが知られている。

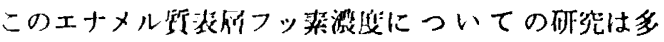
く, 现任では Weatherell ら('72) ${ }^{1)},\left({ }^{\prime} 73\right)^{2)},\left({ }^{2} 75\right)^{3)}$, ('77) ${ }^{4,5)}$, Masenden ('75) ${ }^{6)}$, Jones ('78) ${ }^{7)}$, Richard $\left({ }^{\prime} 77\right)^{8)},\left({ }^{\prime} 79\right)^{9)}$, Koulourides ('79) ${ }^{10)}$ らの研究により,

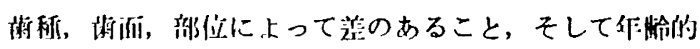
な倠化のあることが州らかにされている。

また，珢近小垭('79) 11,12)により，将来㑣体のう蚛活 顶性（贸受性）を践别するための川们で，生体における

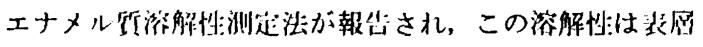

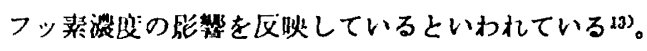

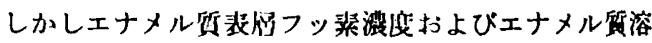
解性の变化について, 䛧牙の沙山闹後, さらに作隃的な 迎水をしたものは少ない。また菌面㓢，あるいは激位別 にそれらの周係を朋らかにしたものもない。

さらにこれまでフッ化物等の効果非定の一つとして抜 去涽牙を用い，その海冠の一部を刘照とし，フッ化物を 作用させた他の部位と比校してフッ素の收り込み盘を求 めるという方法が多く用いられて来た。

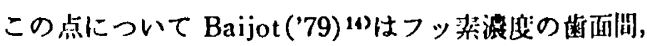
部位阔の宦のあることがほぼ倠かとなっている現在，そ の方法には周題のあることを指摘している。

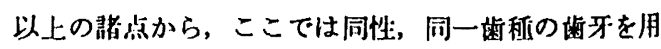

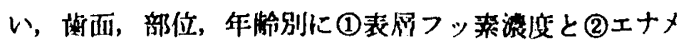

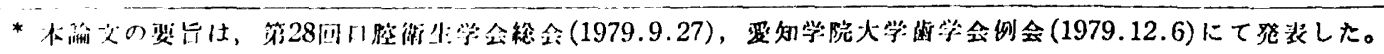

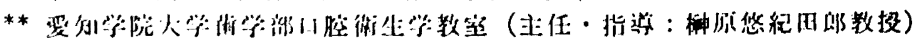

* Department of Preventive Dentistry and Dental Public Health, School of Dentistry, Aichi Gakuin Unir'ersity, Nagoya., Japan (Dirctor: Prof. Yukitaro SAKAKIBARA) 非和55年 3 月1 1 受付 
ル颀溶解性を㭘吋し，更に両者の関係を検璟すること と、(3この実娩を行うために同一部位でエナメル所溶解 性とフッ素浱度を合せて测定する方法について梌郡する ことを目的としてこの破究を行った。

\section{材料と方法}

\section{1. 実験材料}

実倹に用いた歯牙はすへてて女性の健全抜去下頻第一小 曰甫である。

これを次のようにI〜IVの年跉样に分けた。

I 群 (未荫出歯) $7 \sim 10$ 藏 平均 8.1藏 10歯

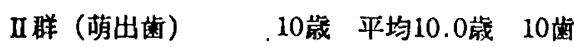

III样（萌出歯） 16 19歳 平均17.2嵅 10菌

IV 群（荫出歯） 25 70歳 平均45.0歳 10 画

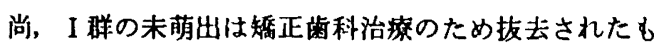
のである。

各歯牙は10\%ホルマリン溶波中に保存し，実駼に先立 って24時阙流水下に浸清した後, 自然乩燥したものを用 いた。

\section{2. 実欶方沠}

中垣の方法を基喏に，Fig. 1 の手順で行った。

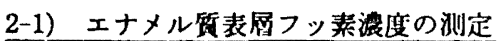

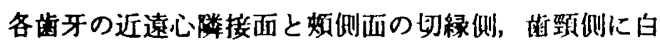
斑，着色などを可及的に避けて，直径 $3 \mathrm{~mm}$ のウインド ウをパラフィンワックスで作成した。以後崡面, 部位
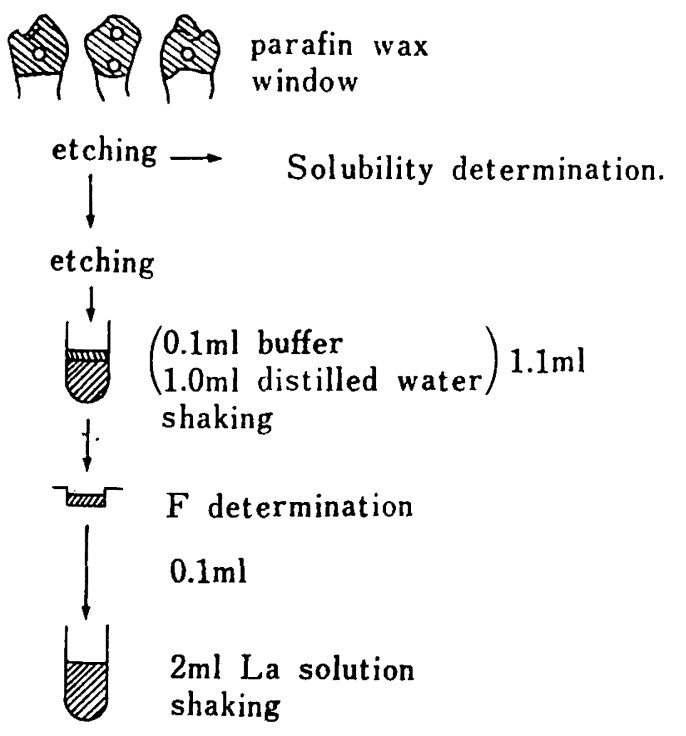

\section{Ca determination}

Fig. 1 Experimental procedure

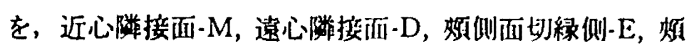
侧面歯影侧-C の略号で褺わすことにする。

エナメル犋溶解性测定のためエナメル所を 1 网採䛀し た後, 同一のウインドウに $0.5 \mathrm{M}$ 過㙁函酸 $2 \mu \mathrm{l} 1$ 分洲 作用させ，樋径 $5 \mathrm{~mm}$ 厚さ $2 \mathrm{~mm}$ のスポンジでこれを 吸収した。尚，この恃に便用したスポンジはカネボウ化 精品 KK 製スポンジチーフで，中性洗剂で洗浄後水洗

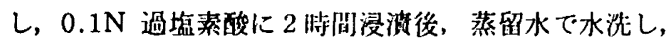

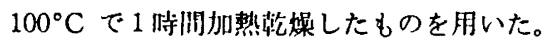

次々にこのスポンジを蒸留水 $1 \mathrm{ml}$ に TISABIII（才 リオン社製) $0.1 \mathrm{ml}$ を汃えた試踰管内一投入し，1 分間

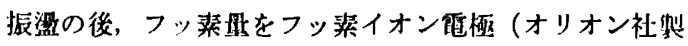
96-09型）で测定し，その後この倹体から0.1 $\mathrm{ml}$ 陚料を とり, $0.3 \mathrm{mg} / \mathrm{ml}$ ランタン溶没 $2 \mathrm{ml}$ を含む武颗符内に 注入後, カルシウム舴を京子吸光分析法（1.1立-perkinElmer 303型) で测定した。

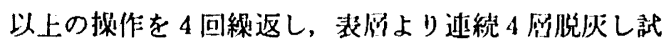
料を得た。

次に得られたカルシウム㨁から小埴ら13)の少法によ り，深さを算出しその深さでのフッ掏灌度を求め，表们 から深屑にかけての 4 力所の测定点に抢けるフッ秦浱度

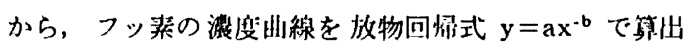
した。

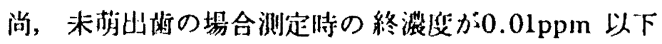
といら極めて低い濃度となることが考えられたので, 测 定摽淮液には $0.1 ， 0.05,0.025,0.01,0.005 \mathrm{ppm}$ の各 標淮液を用いた。

\section{2-2）エナメル钎济解性の洲定}

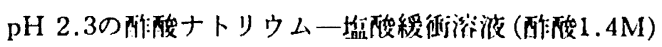
$2 \mu \mathrm{l}$ を 1 分䦌作川させ，スポンジにこれを吸収し， 0.3 $\mathrm{mg} / \mathrm{ml}$ ランタン溶波 $2 \mathrm{ml}$ を含む試㤉箈の中一投人し,

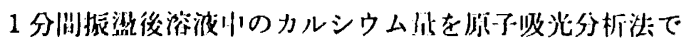
测定した。

\section{結果}

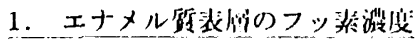

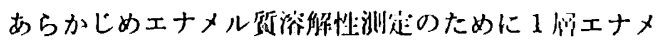

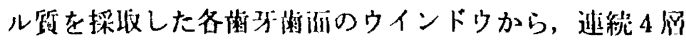

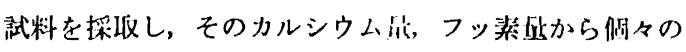

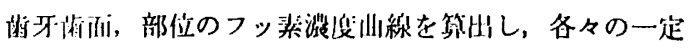
の深さに扩けるフッ染イオン滥度を水めることができ た。

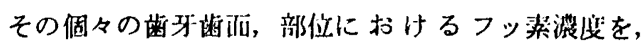
$0.5,0.8,1.0,5.0,10.0,20.0 \mu \mathrm{m}$ の染さで筑山し， 
Table 1 Fluoride concentration in different regions of lower first premorals of four age groups

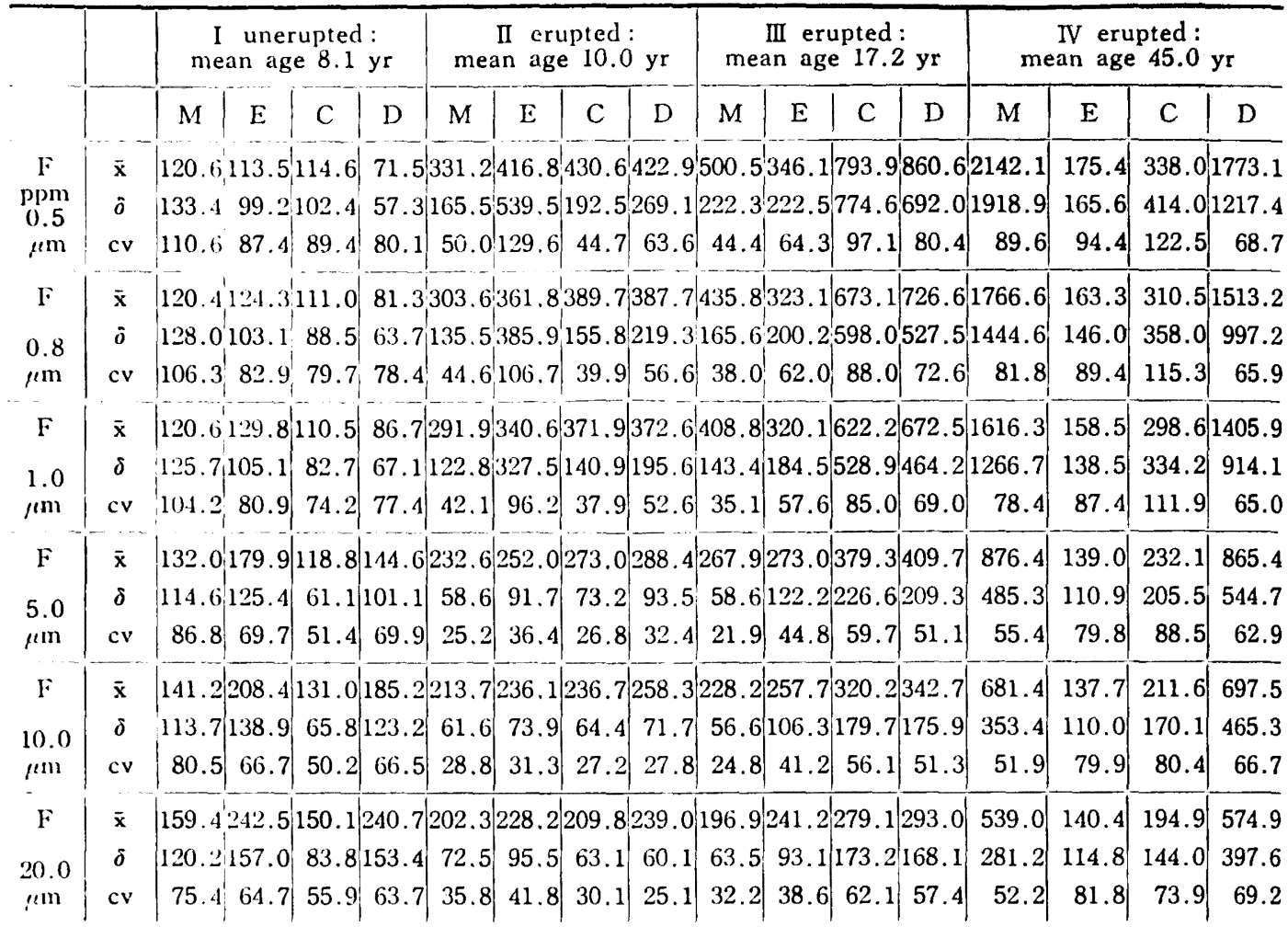

$\overline{\mathbf{x}}$ : mean $\hat{o}$ : standard deviation $\mathrm{cv}$ : coefficient of variation $\mathrm{M}$ : mesial surface $\mathrm{E}$ : near the biting edge of buccal surface $C$ : near the cervical portion of buccal surface

D : distal surface

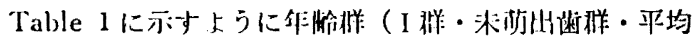

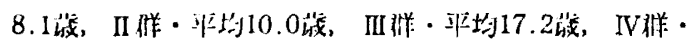

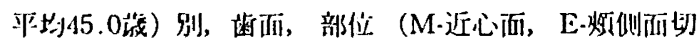

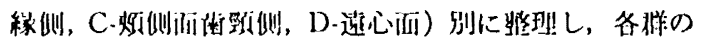

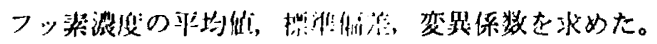

II，III，IV样では各橉侕，部位とも寸べて裴居から梁

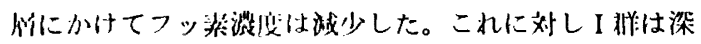

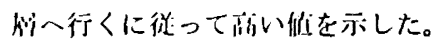

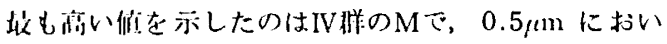
て2142.1ppm であり，逆に级も低い值仕 I 貄のDで， 0.5 /m において71.5ppm であった。

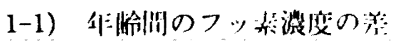

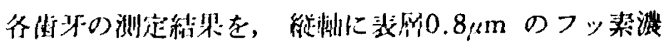

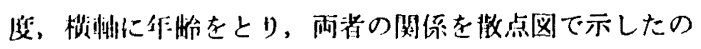
が Fig. 2 である。

佔湴，部位別にみると， $\mathrm{M}, \mathrm{D}$ の隣接面と $\mathrm{E}, \mathrm{C}$ の 烦仙而とは样相がまったく罢なる。

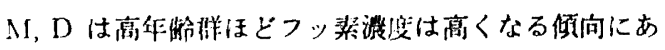

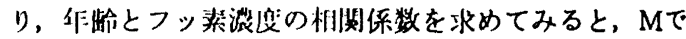
$\mathrm{r}=0.597(\mathrm{P}<0.01)$ Dで $\mathrm{r}=0.663(\mathrm{P}<0.01)$ と有意 で，かつ，かなりの帅い相㜀々係が琶められたのに対 し，E，Cではそのような一定打问の変化はなく，それ

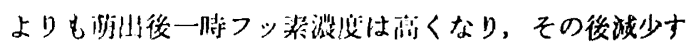
るという洒!向が琵めたれた。

Table 1より作掵详别の平均倾と95\%信頼限界を図 にしたのが Fig. 3 である。 M. D では I 群と他群との 䦌に明らかな兴があり，II样とは $5.0 \mu \mathrm{m}$ まで，且样と

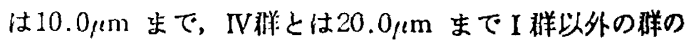

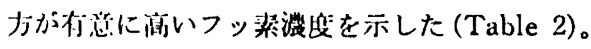

河後は，M，D において $20 \mu \mathrm{m}$ までIV样が样より

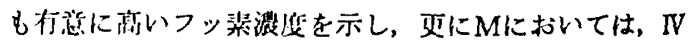
样はIIIよりも20.0 亿

Eでは II 样は I 样より $0.5 \mu \mathrm{m}$ まで有澺に高く，四群 は I 样より $1.0 \mu \mathrm{m}$ まで朾意に扁いフッ染浱废を示した。 またCではII，而群ともに $10.0 \mu \mathrm{m}$ までI样より有意に 部いフッ染淺伐であった。 

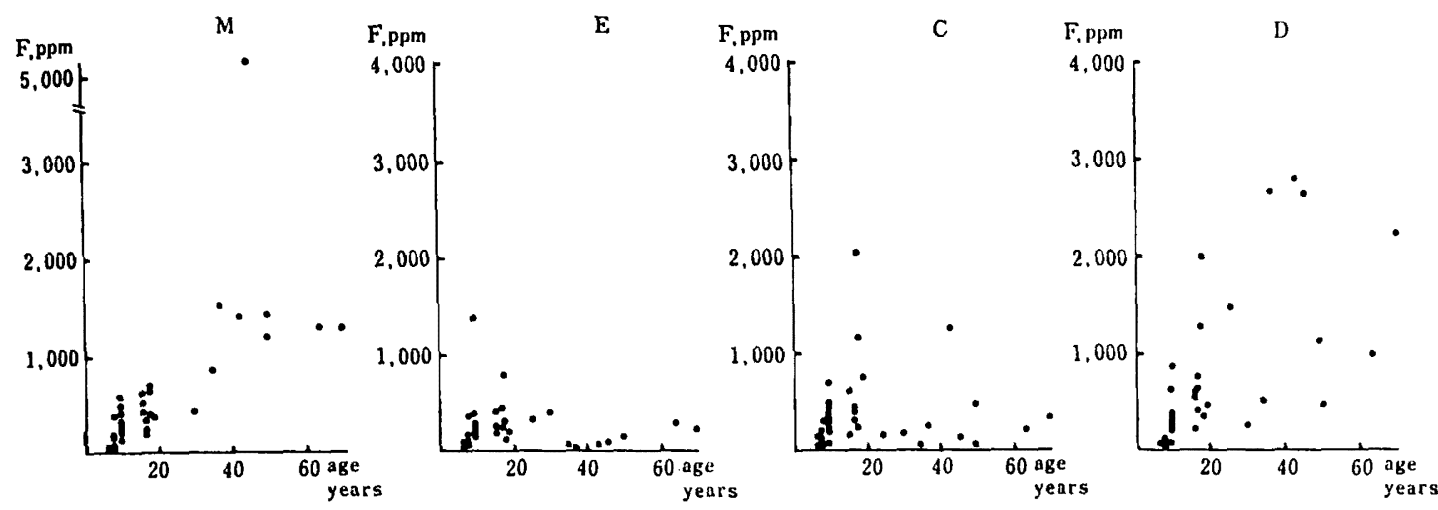

Fig. 2 Variation in Fluoride concentration at the depth of $0.8 \mu \mathrm{m}$ with age $M$ : mesial surface, $E$ : near the biting edge of buccal surface, $C$ : near the cervical portion of buccal surface, $D$ : distal surface
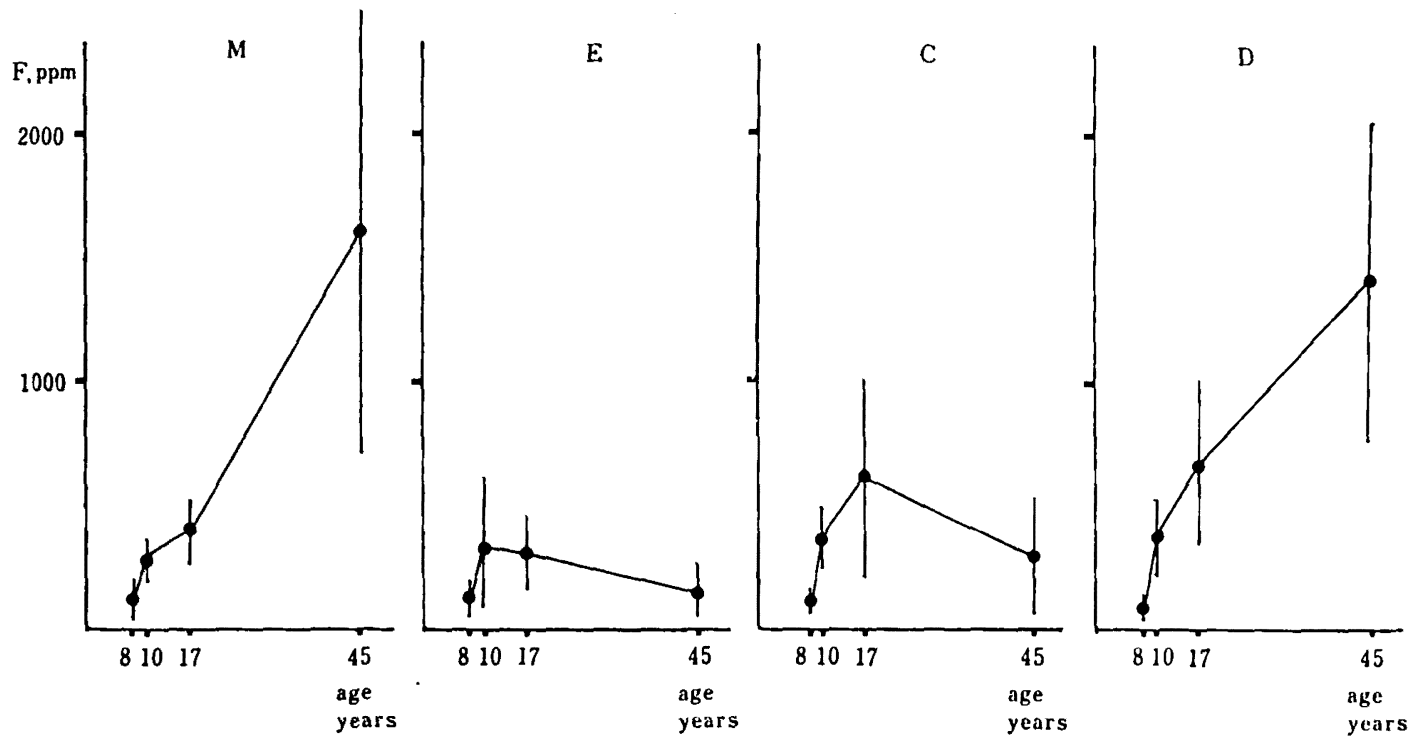

Fig. 3 Variation of mean values in fluoride concentration at the depth of $0.8 / \mathrm{m}$ with age. The vertical bars indicate the $95 \%$ confidence ranges.

$M$ : mesial surface, $E$ : near the biting age of buccal surface, $C$ : near the cervical of buccal surface, D: distal surface

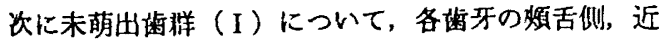

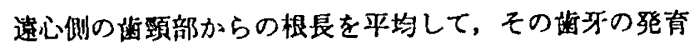

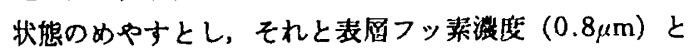
の間の関係をみたのが Fig. 4 である。

両者の間に有意な相関は得られなかったが, 画根が長 くなるにつれて，フッ奖浱媛が高くなる㑯向がみられ た。

1-2) 遒面，部位閒のフッ素浱度の差

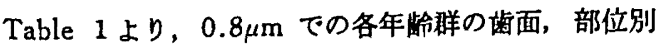

の平均フッ奖旗度を示したのが Fig，5である。I，

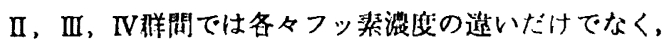

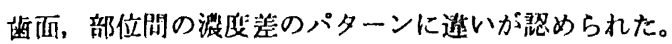

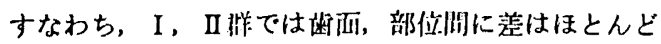

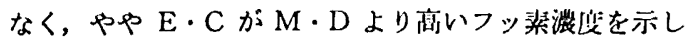
ているのに対し，III，IV样では $\mathrm{M} \cdot \mathrm{D}$ の方が $\mathrm{E} \cdot \mathrm{C}$ 上 り禀いフッ素搌度を示すようになった。

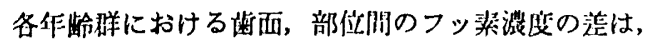
III群で, $1.0 \mu \mathrm{m}$ までDがEより有意に部く，IV样では 
Table 2 Comparison of the mean fluoride concentration among the age groups

\begin{tabular}{|c|c|c|c|c|c|c|c|}
\hline \multicolumn{2}{|c|}{ depth from surface: } & 0.5 & 1.0 & 3.0 & 5.0 & 10.0 & $\begin{array}{r}20.0 \\
\mu \mathrm{m}\end{array}$ \\
\hline \multirow{6}{*}{$\begin{array}{l}\text { I } \\
\text { I } \\
\text { I } \\
\text { II } \\
\text { II } \\
\text { III }\end{array}$} & I $\sim$ II & $* *$ & * & * & - & - & - \\
\hline & I $\sim$ III & $* * *$ & * & * & * & * & - \\
\hline & I $\sim$ IV & * & * & $*$ & $*$ & * & * \\
\hline & $\mathrm{II} \sim \mathrm{III}$ & - & - & -- & $\ldots$ & - & - \\
\hline & II $\sim$ IV & * & * & $*$ & $*$ & * & $*$ \\
\hline & III $\sim$ IV & * & * & $*$ & $*$ & * & $*$ \\
\hline
\end{tabular}

\begin{tabular}{|c|c|c|c|c|c|c|c|}
\hline \multicolumn{2}{|c|}{ depth from surface: } & 0.5 & 1.0 & 3.0 & 5.0 & 10.0 & $\begin{array}{r}20.0 \\
\mu \mathrm{m}\end{array}$ \\
\hline \multirow{6}{*}{ C } & I $\sim$ II & $* * *$ & $* *$ & $* *$ & $* *$ & $* *$ & - \\
\hline & I $\sim$ III & $* *$ & * & * & * & * & - \\
\hline & $I \sim I V$ & - & - & - & - & - & - \\
\hline & II $\sim$ III & - & - & - & - & - & - \\
\hline & $\mathrm{II} \sim \mathrm{IV}$ & - & - & - & - & - & - \\
\hline & $\mathrm{III} \sim \mathrm{IV}$ & - & - & - & - & - & - \\
\hline \multicolumn{2}{|c|}{ depth from surface: } & 0.5 & 1.0 & 3.0 & 5.0 & 10.0 & 20.0 \\
\hline \multirow{6}{*}{ D } & I $\sim$ II & $* *$ & ** & ** & $* *$ & - & - \\
\hline & I $\sim$ III & $* *$ & $*$ & $*$ & $*$ & * & - \\
\hline & $\mathrm{I} \sim \mathrm{IV}$ & $* *$ & $*$ & $*$ & * & * & $*$ \\
\hline & II $\sim$ III & - & - & - & - & - & -- \\
\hline & II $\sim$ IV & $* *$ & $*$ & $*$ & * & * & $*$ \\
\hline & III $\sim$ IV & - & - & - & - & - & - \\
\hline
\end{tabular}

statistical difference * $: \mathrm{P}<.05 \quad$ ** $: \mathrm{P}<.01 \quad$ *** $: \mathrm{P}<.001$

I : unerupted : mean age $8.1 \mathrm{yr}$ II : erupted : mean age $10.0 \mathrm{yr}$ III : erupted : mean age $17.2 \mathrm{yr}$ IV : erupted : mean age $45.0 \mathrm{yr}$
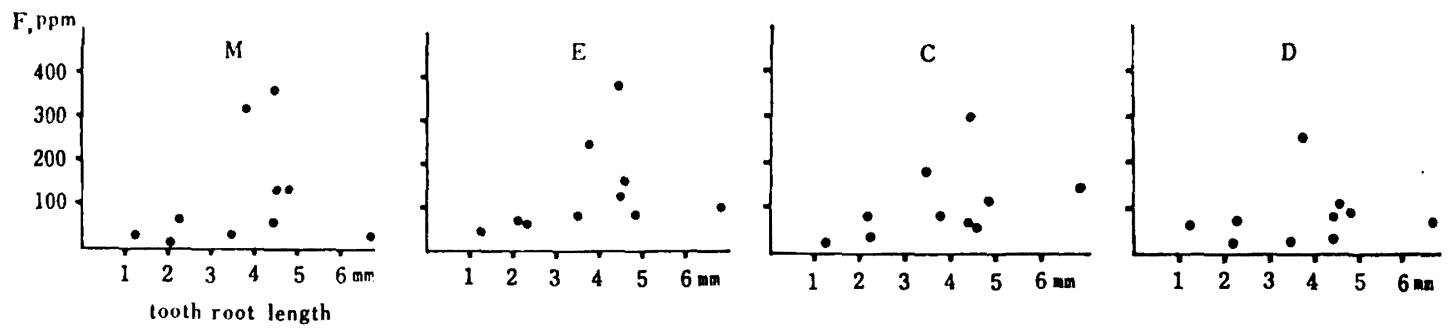

Fig. 4 Relationship between fluoride concentration at $0.8 \mu \mathrm{m}$ depth and tooth root length

$\mathrm{M} \cdot \mathrm{D}$ が $\mathrm{E} \cdot \mathrm{C}$ よりも $20.0 \mu \mathrm{m}$ まで有意に高いフッ素 搌度を示したが，これ等以外の歯面，部位䦌には有意な 差は哭められなかった。

\section{1-3）丧屋エナメル所中のフッ素溜度のバラッキ}

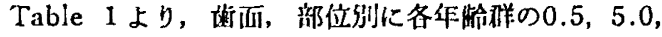

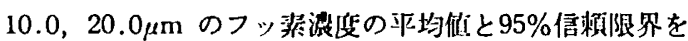
Fig. 6 に示した。

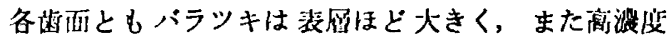
になるほどバラッキが大きくなる倾们にあった。また Table 1 の変思绿数について梁さによる変化を図にし てみると（Fig. 7）だいたい5.0 $\mu \mathrm{m}$ のあたりで安定する ようであった。

このバラッキはI样で大きく，次に山倠で小さくなっ

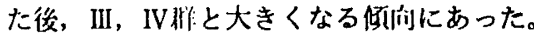

さらに鲆洏，部位别にみると，I，II样では抈らかな 美はないか，III，IV样となるにつれ，E・Cのバラッキ
が大きくなる倾向が琹められた。

\section{2. エナメル犋溶解性}

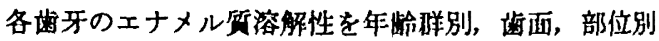
に巫均值と標潐偏差, 变異係数で示したのが Table 3 である。

I样は他の样に比ぺエナメル兵溶解性が高くことに Mは $1.91 \mu \mathrm{g}$ と最も高い㐭を示した。これに対し层低值

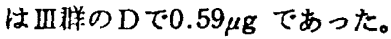

\section{2-1）年陯间のエナメル罂溶解性の差}

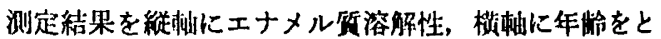
って再者の関係を做点図に示したのが Fig.8である。

各齿面，部位ともにほほ似た傾向を示し，荫出後急速 に溶解性は城少し、一定になる佰向であった。

又，作䏩样の平均值の茬をみると，いずれて歯西，部 位でもI群とそれ以外の洋との間にのみ，P<0.05 0.01 で有意差が㤎められ，明らかに未模出齒（I）は萠 


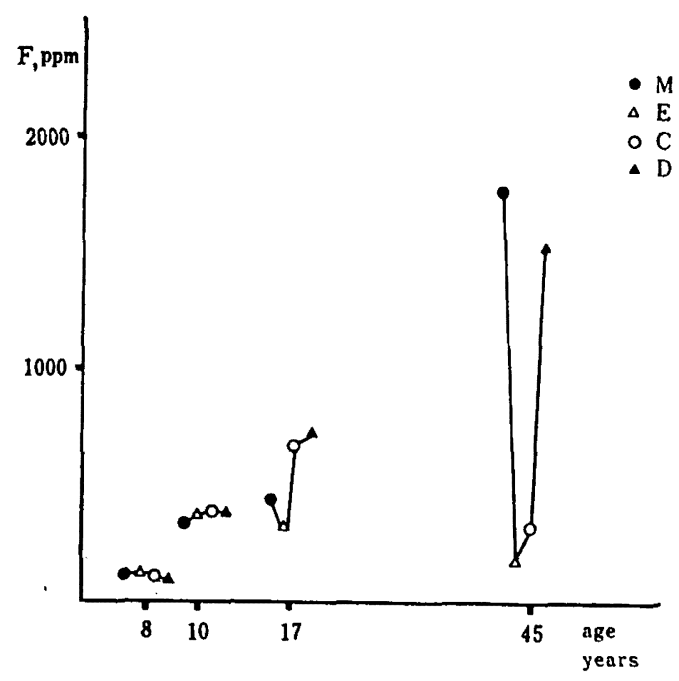

Fig. 5 Variation in fluoride concentration at the depth of $0.8 \mathrm{um}$ with age on different surfaces of lower first premolars

出歯 (II 〜V) より エエナメル斦溶解性が高かった (Fig. 9)。

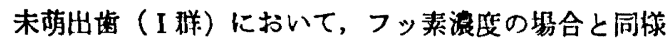
に遴根艮をめやすとした成長状隹とエナメル質溶解性と の相関々係をみたのが Fig. 10である。

齒根が長くなるに従い, エナメル梊溶解性は明らか に減少する倾向にあり，Mでは $\mathrm{r}=-0.607(\mathrm{P}<0.05)$ と有意でかなりの関連を示す負の相関係数が 認められ た。
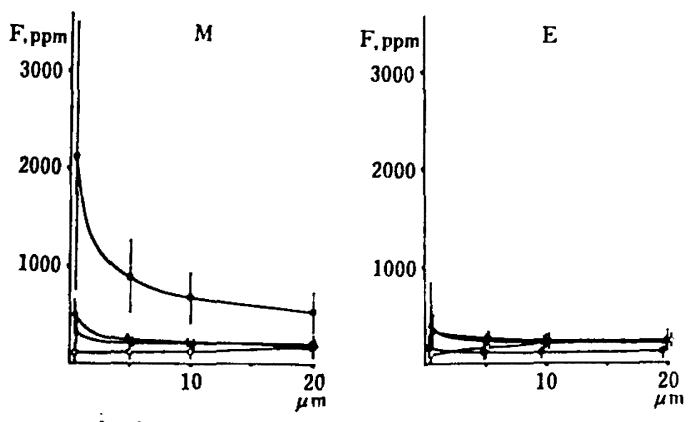

\section{2-2）菌西間のエナメル翼溶解性の差}

Fig. 11に示すように【椎とII，III，IV椎とでは则ら かにェナメル毁溶解性の掬面, 部位間の差のパターンが

䀯なっていた。

すなわち，I群では $\mathrm{M} \cdot \mathrm{D}$ と $\mathrm{E} \cdot \mathrm{C}$ の溶解性はほぼ 同じ倾向にあるのに対し，II，III，IV样ではいずれも $\mathrm{M} \cdot \mathrm{D}$ の片が $\mathrm{E} \cdot \mathrm{C}$ よりもエナメル㹞溶解性が这に低 い做を示す傾向にあった。

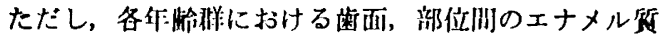
浴解性にはいずれも有您な望は琹められなかった。

\section{2-3）エナメル资溶解性のバラッキ}

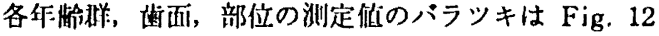

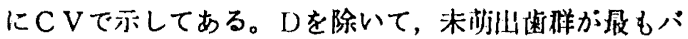
ラッキが少なく，啇作㱓佯ほど大きくなる倾向にあった が,これは特に瞵接画に括いて著しかった。

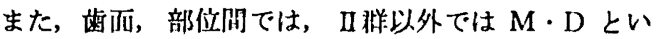
5隣接面の方が $\mathrm{E} ・ \mathrm{C}$ より大きなバラッキを示した。

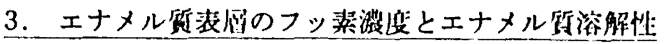
関係

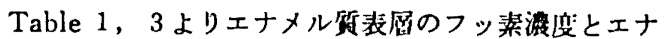
メル罂溶解性の関係をみてみる。

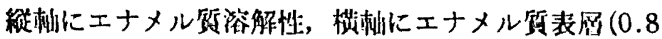

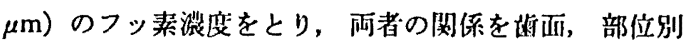
に敬点図で示したのが Fig. 13である。

すべての歯面, 部位でフッ烮蕽度上乐にともなうエナ メル梊溶解性の娍少の倾向がみられたが，その状㙫は $\mathrm{M} \cdot \mathrm{D}$ と $\mathrm{E} \cdot \mathrm{C}$ とで大きく罳なり，また $\mathrm{M}$ と $\mathrm{D}, \mathrm{E}$ と Cの䦌でも多少差が認められた。
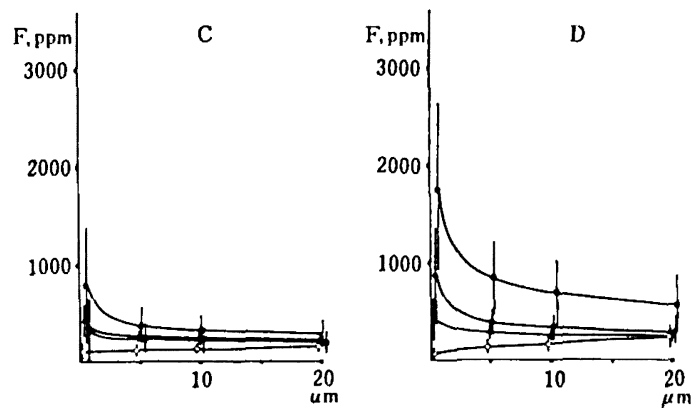

Fig. 6 Fluoride distribution curves of four age gronps in lower first premolar. The vertical bars indicate the $95 \%$ confidence ranges.

O I (unerupted: mean age 8.1yr) $\triangle$ II (erupted : mean age 10.0yr)

- III (eurpted: mean age 17.2yr) aIV (erupted: mean age 45.0yr)

$\mathrm{M}$ : mesial surface, $\mathrm{E}$ : near the biting age of buccal surface, $\mathrm{C}$ : near the curvical portion of buccal surface, $D$ : distal surface 

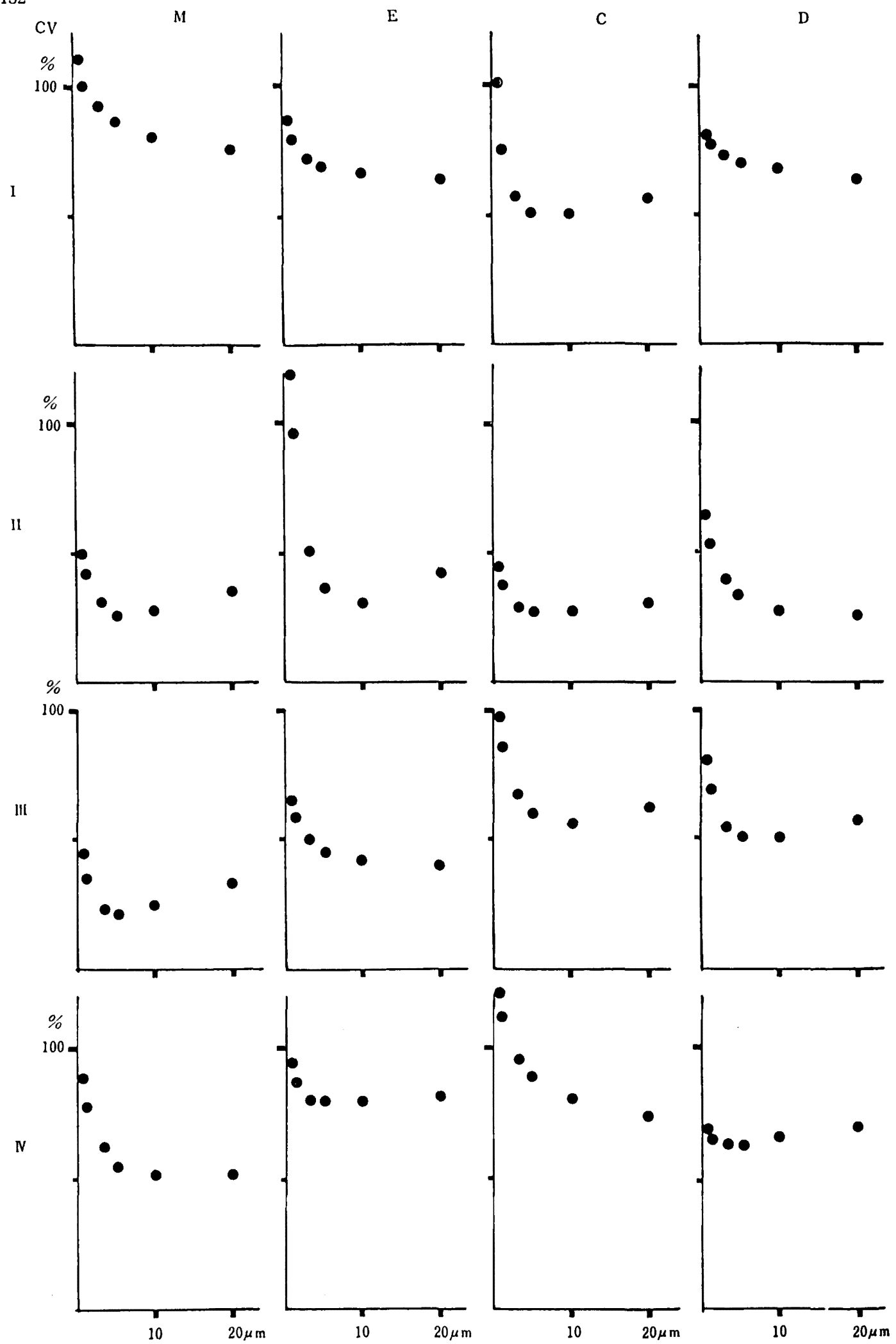

Fig. 7 Changes in coefficient of variation of the fluoride concentration 
Table 3 Enamel solubility in different regions of lower first premolars of the four age groups

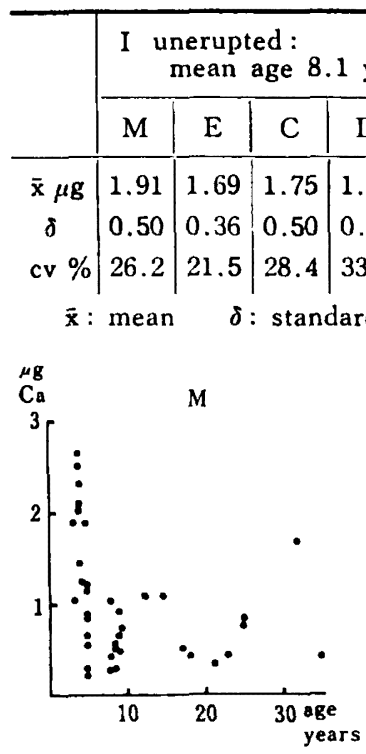

\begin{tabular}{|c|c|c|c|c|c|c|c|c|c|c|c|c|}
\hline $\begin{array}{l}\text { II erupted : } \\
\text { mean age } 10.0 \mathrm{yr}\end{array}$ & \multicolumn{3}{|c|}{$\begin{array}{c}\text { II erupted: } \\
\text { mean age } 17.2 \mathrm{yr}\end{array}$} & \multicolumn{4}{|c|}{$\begin{array}{c}\text { IV erupted: } \\
\text { mean age } 45.0 \mathrm{yr}\end{array}$} \\
\hline & $\mathrm{M}$ & $\mathrm{E}$ & $\mathrm{C}$ & $\mathrm{D}$ & $\mathrm{M}$ & $\mathrm{E}$ & $\mathrm{C}$ & $\mathrm{D}$ & $\mathrm{M}$ & $\mathrm{E}$ & $\mathrm{C}$ & $\mathrm{D}$ \\
\hline & 0.78 & 0.90 & 0.85 & 0.73 & 0.60 & 0.82 & 0.87 & 0.58 & 0.77 & 0.96 & 0.89 & 0.81 \\
& 0.35 & 0.41 & 0.27 & 0.19 & 0.24 & 0.27 & 0.37 & 0.25 & 0.40 & 0.42 & 0.30 & 0.57 \\
& 44.7 & 45.4 & 31.6 & 26.2 & 39.6 & 32.8 & 41.9 & 42.5 & 52.5 & 43.6 & 33.6 & 70.7
\end{tabular}
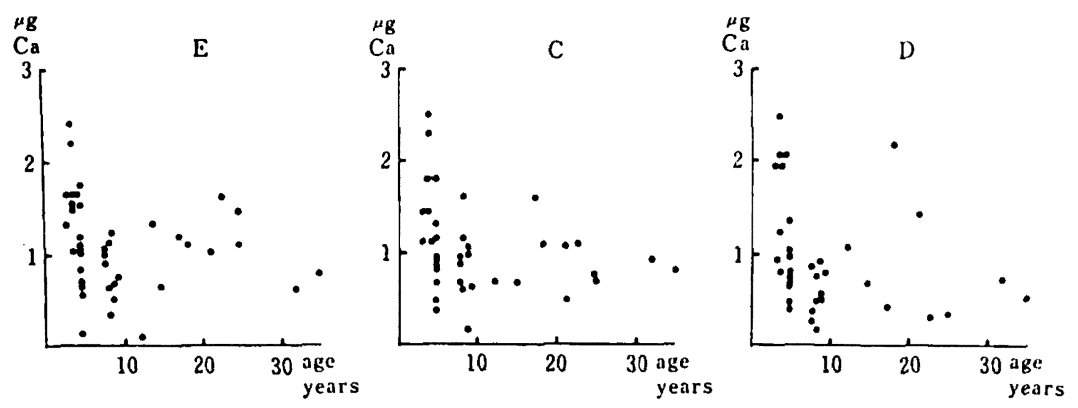

Fig. 8 Variation in enamel solubility with age

$M$ : mesial surface, $E$ : near the biting age of buccal surface, $C:$ near the cervical portion of buccal surface, D : distal surface
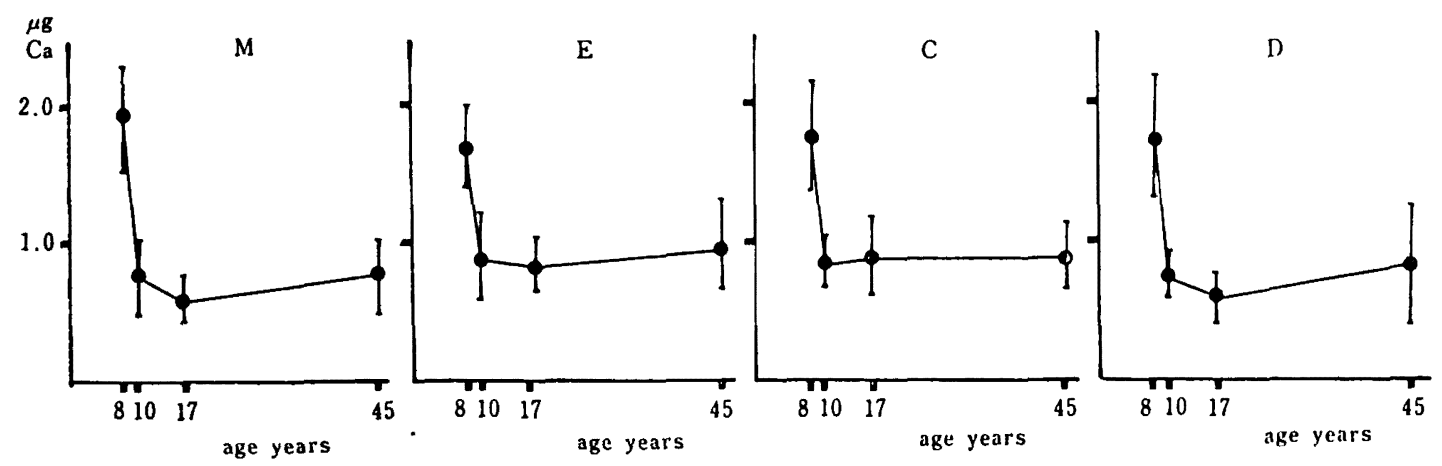

Fig. 9 Variation in enamel solubility with age. The vertical bars indicate the $95 \%$ confidence ranges.

$M$ : mesial surface, $E$ : near the age of buccal surface, $C$ : near the cervical portion of buccal surface, D : distal surface
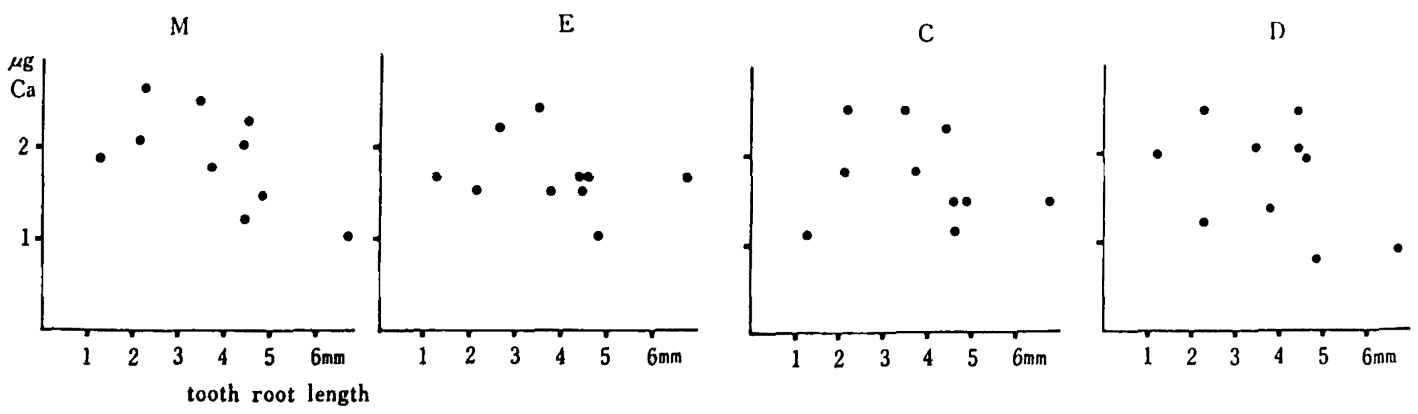

Fig. 10 Relationship between enamel solubility and tooth root length 


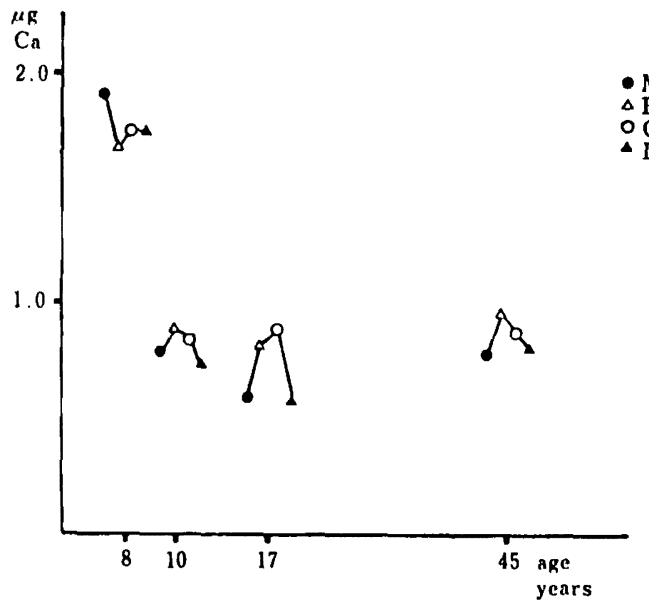

Fig. 11 Variation in enamel solubility with age on different surfaces of lower first premolars

- $\mathrm{M}$ : mesial snrface, $\Delta E$ : near the biting age of buccal surface, $O C$ : near the cervical portion of buccal surface, $\Delta \mathrm{D}$ : distal surface

\section{考 察}

今国の破究の日们は次の3 点であった。

(1) Weatherell $(72)^{1)},\left({ }^{\prime} 73\right)^{2)},\left({ }^{2} 75\right)^{3)},(77)^{4,5)}$, Aasenden ('75) ${ }^{63}$, Jones ('78) ${ }^{7)}$, Richard $(' 77)^{8)}$,

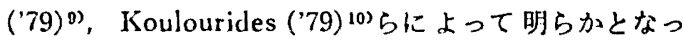

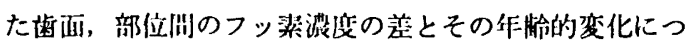

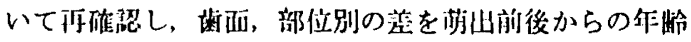
的変化について検郡すること。

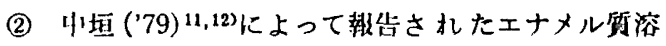

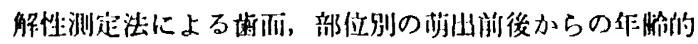

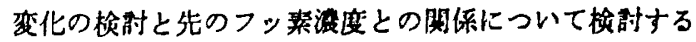
こと。

(3) 以上の实䮖を行らために, 同性, 同一係の画牙に ついて，同一部位でエナメル犋溶解性とエナメル澌表居

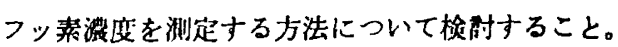
以下，本㼋究に関係して凬題となる諸点を考察する。

\section{1. 材料と方法について}

\section{1-1) 材料}

笑敛に使用する拔去菌牙については，Aasenden

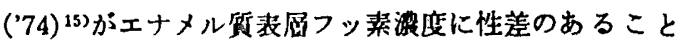
を報告していることからこれを考度し，本実験は女性 の㴹牙に統一した。

男性の齿牙については今後梌即する予定である。

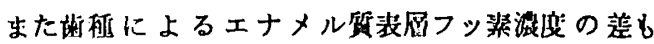

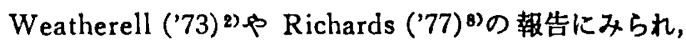
エナメル㑭溶解性も菌称による羑のあることが中垣ら ('79) 18)によって報告されていることから下影第一小罒 菊に限定した。

下预第一小画药は末荫出歯が比較的入手し易く，今回 の作㱓的な検郡を行う実駼に適した蒌牙であった。

しかし，標本とする歯牙の性，歯䄬を限定したため, 摽本数が制約され，このことが头䀶絬果の偏りにある程 度影阷したことは十分考えられる。

今回はすべて10\%ホルマリン溶液中に保存した歯牙を 用いて実験を行った。このホルマリンが芷西に影響する かどうかは今後の検討が必要であるが, 実験結果には, ホルマリンの作用で药面，部位，年龄间の差が燰蔽され るようなことはなく，本实験において特に支障は生しな かったと思われた。

\section{1-2) ウインドウ形成}

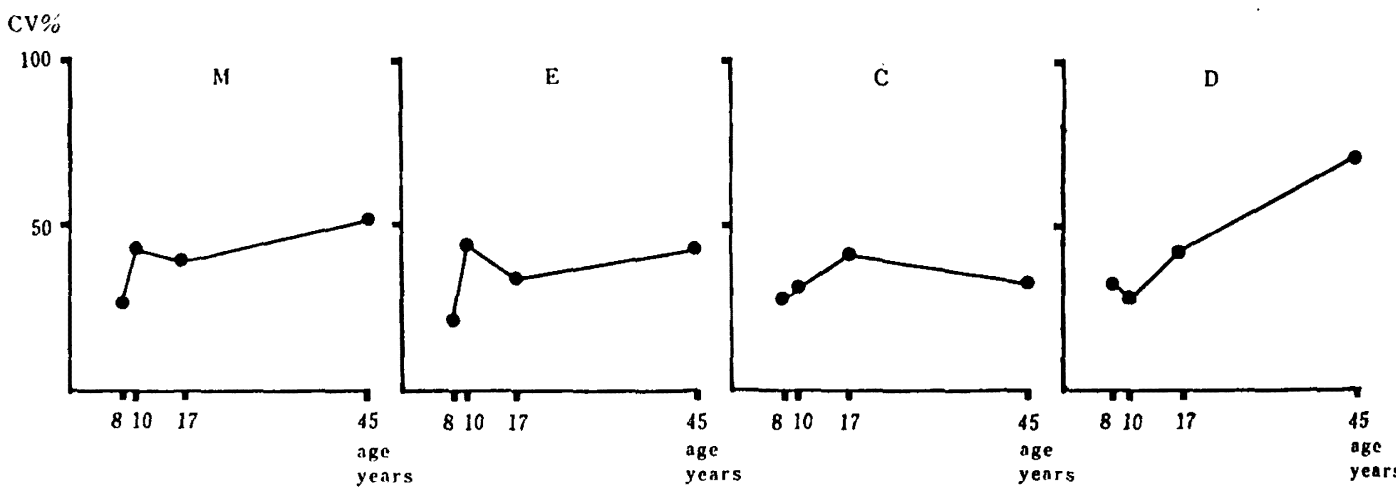

Fig. 12 Variation in dispersion of enamel solubility with age $M$ : mesial surface, $E$ : near the biting age of buccal surface, $C$ : near the cervical portion of buccal surface, $D$ : distal surface 

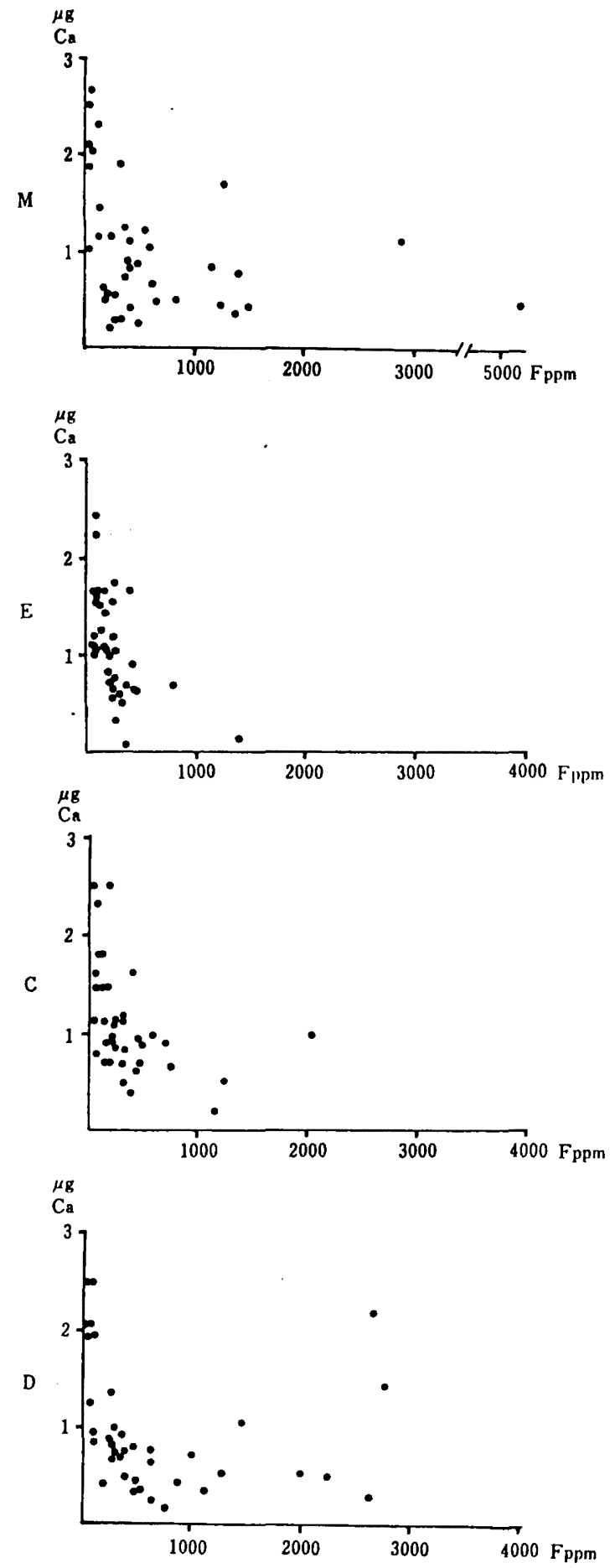

Fig. 13 Relationship between 'luoride concentration at $0.8 \mu \mathrm{m}$ clepth and enamel solubility in lower first pre. molars
中垣ら ('79) 193はスコッチテープを用いてウインドウ を形成し测定にあたった。しかし，同一ウインドウに杭 実験のように合計 5 回，計 5 分间エナメル澌探取用の㭼 液を作用させるような場合スコッチテープの接着うに[傮] 題が出て来る。

つまり，涉方行への漏洩 (side etching) のため正碓 な陚料探取ができなくなることが十分考えられた。

このため今回はバラフィンワックスでウインドウを作

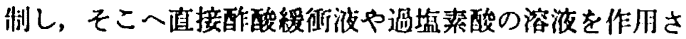
せこれを脱カルシウム，脱フッ素処理したスポンジで 回収する力法を用いた。

\section{1-3) フッ絜港度测定}

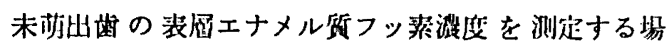

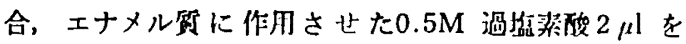
TISABIII（オリオン社剩） $0.1 \mathrm{ml}$ を含む $1.1 \mathrm{ml}$ 蒸留水 币へ入れると，その测定時の終溜度は0.01ppm 以下と なることが十分推测された。

しかし，從来，オリオン社のフッ絜イオン雪極は0.02 $\mathrm{ppm}$ を湘定限界としている24,25)。このため0.01ppm と

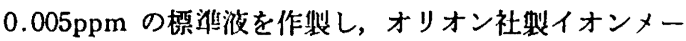
ター407型の $\mathrm{mV}$ ゲージを俅用してスタンダード川線

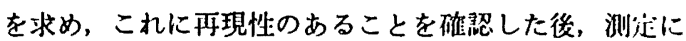
あたった。

\section{2. 試料採取方法}

従来，抜去莼牙を用いてフッ化物の取り込み量などの 検討を行う場合, Mellberg ('65) 17), McCann ('69) 18), 鈴木('73) ${ }^{19)}$ ， Richard ('79) 20)等の用いた，エナメル斦 を分割し，小片にしてその1片を対祭とし，他の小片にフ ッ妻化物を作用させて比敕する方法や，小佳野('75) 21), Kirkegaard ('77) 22), 商栝('78) 23), 中坦('79) 13)らの行 ったように同一䔦面の一部を刘愍とし，他の一部にフッ 化物を作用させて比校梌狽する方法がとられて来た。

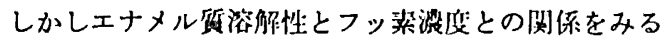

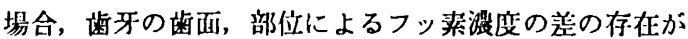
十分推测できるのであるから，たとえ同一歯而であって

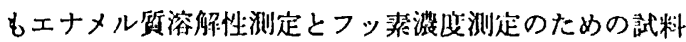
採取の位直が罢なるのは論理的におかしいことになる。

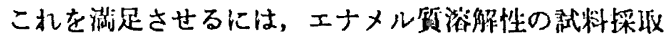
とフッ秦灌底测定のための試料採收を同一激位で垁施す ることが必要となる。

Baijot ('79) 14) も同じ点に渚目し,フッ猆の取り込み店 测定の場合，蓷芭粒子を用いた放财化分析の忘历 $20,27,7)$ で同一桨而の同一部位から刘贸の倠とフッ化物念爪後の

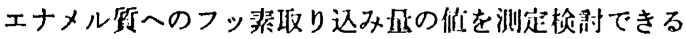




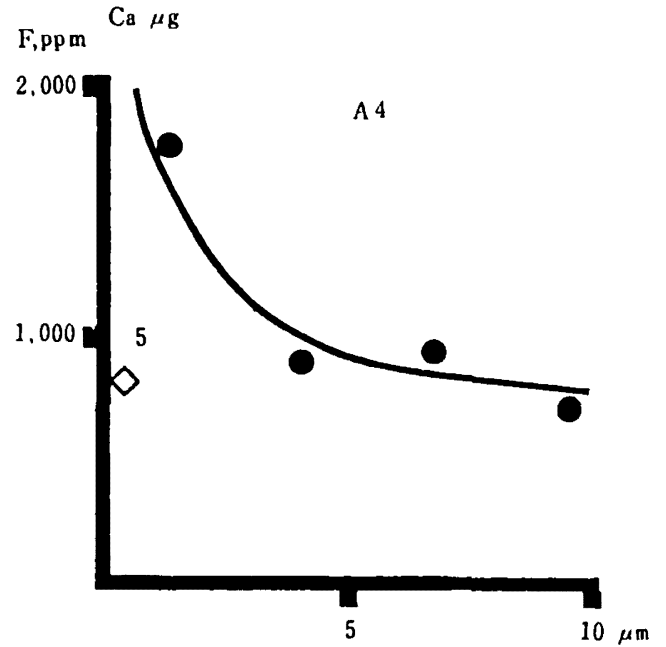

depth from surface

Fig. 1.1 Fluoride distribution curve of upper incisor

上報皆している。

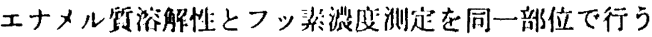

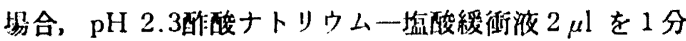
闲作用させ，1局脱灰したことにより，その後その同じ

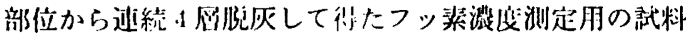
に何らかの影然が出て，放物回惕川線を求めるのに支障 をきたすのではないかという点汃開題となる。

この点について 先に菇者ら('77) ${ }^{28)}$ は抜去上影中切㻌 を用い，今日と同椂に酢酸釋行腋でエナメル所浴解性をを

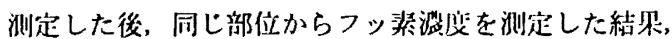
Fig. 14に示寸ように放物回熳式と十分一致し，溶解性 とフッ深岶度を合せて洲;沋できることを報告した。

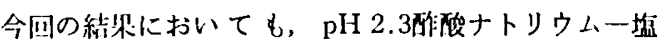

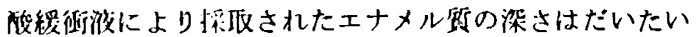
$0.19 \mu \mathrm{m}$ 位で， $0.5 \mathrm{M}$ 過焦续酸によるそ机は $3 \sim 4 \mu \mathrm{m}$

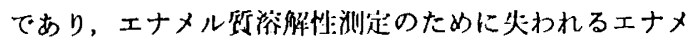
ル質はきわめて少证である。

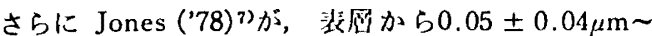

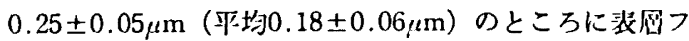
ッ絜泿度のピークがあり，それより㳀い裴局方向の部分

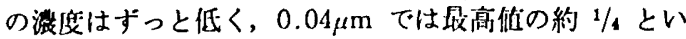
う低湠度を示すことを報告している。

以上の点から， $\mathrm{pH} 2.3$ 酢酸ナトリウム一㙁酸緩矿波

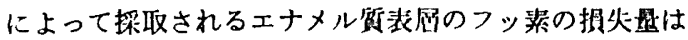

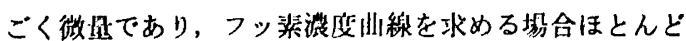
支㒕とならない成と思われる。

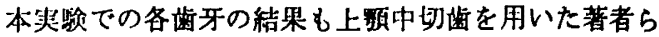
('77) ${ }^{28)}$ の結果, さらにエナメル啠溶解性の测定とフッ 絜湠度の测定の部位を別にした，つまり溶解性测定の能 㛃を受けなかった中垣ら('79) 19)の報告とも一致し，エ

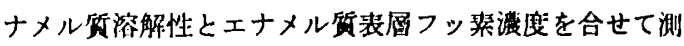
定することが谁認できた。

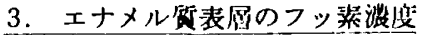

結果に示したように，明らかに年峆的な変化がェナメ

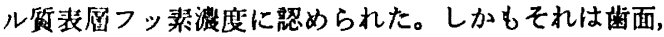
部位によって差のあることも碓かめられた。以下それぞ れについて考繁する。

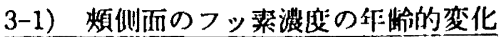

(1) 切縁侧 (E)

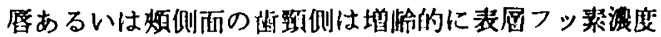

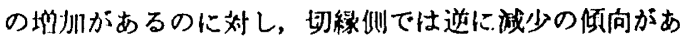
ることは Weatherell ('72)"，('73)2)，('77)4,5)により

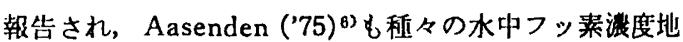
城における13〜15歳の子供に同栐な倾向を琹め,Bishoef

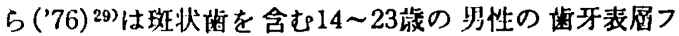
ッ絷搌庭と作跲の䦌に $\mathrm{r}=-0.40$ の有意な㕲関を得てい る。

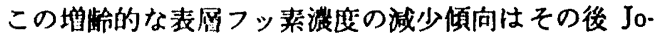
nes ('78) ${ }^{7)}$, Richards $(' 77)^{8)}$, ('79) ${ }^{9,30)}$, Koulourides

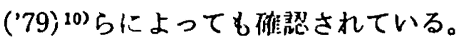

これは，それ以前に多くの報告のあった龉面表屏のフ

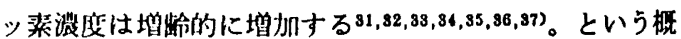
念を大きく変える知見であって,これ迄の砳究では落面， 蔀位別の追冰がなく，あったとしても作跲的な考察，齿 種の考底，及びそれ等の組合せが不十分であったためで ある。

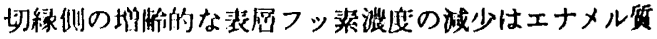
表而の “ナりへり(Wear)” によることが Weatherell

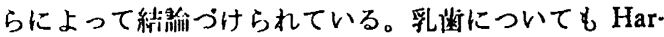

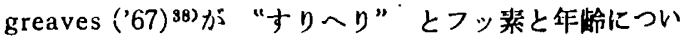
て众尉している。

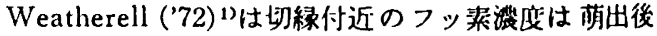

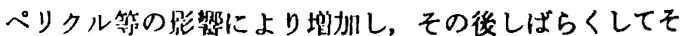
の增加は涉代い状账となった後, “すり・人り”による 诚少が始まるという仮説を立てたが, Aasenden ('75)の) は子想に反し，より早甽に“すりへリ”によるフッ秦の 減少の羿められることを報告している。

また末埍出歯については, Weatherell ('75) ${ }^{9)},(' 77)^{4,3)}$ やSpeins ('78) ${ }^{39)}$, 須贺('73) ${ }^{40)}$ ，('76)(1)らによって婳 冠完成とともにエナメル澌中のフッ雲は城少し，次いで 


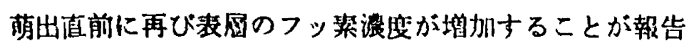
されている。

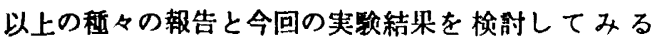
と，むず，第I群の未游出落群について，その菌根展の

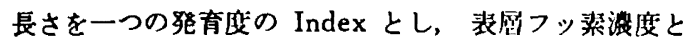
の関係をみると，煩侧面切緑侧に限らず，すべての齿

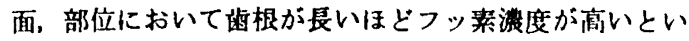
う㑯向がみとめられた。

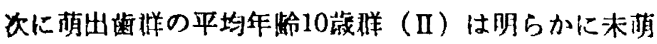

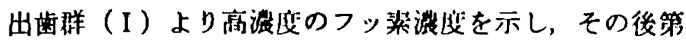

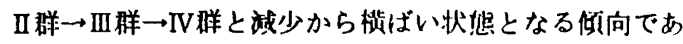
った。

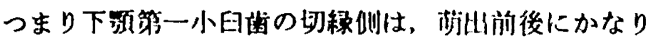
のフッ秦を扳り込み，ついで “すりへり”により㳚少 が生ずるという結果が得られた。これは、これ迄の Weatherell を始めとする栢々の報告と大変よく一致し た。

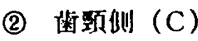

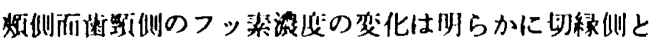

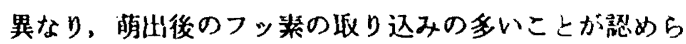
れた。

つまり，作跲洋閏の比較においても，I 群一II 样 $\rightarrow$ III

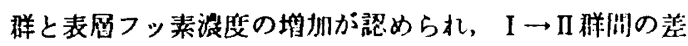

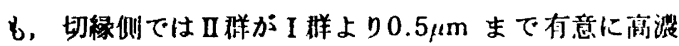
度であったのに対し、菊預僛は $1.0 \mu \mathrm{m}$ むでと、より梁 い属まで川群の方が有意にフッ素が高搌度の分布をして Wた。

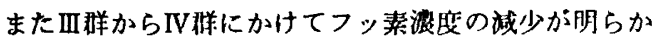
であった。

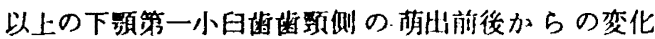
は, 先の切緑侧における変化に比へ“すりへり”の発 生が年龄的に遅れ，それだけフッ䌽の取り込みが增すも のと推测された。

Weatherell ('72) 1), ('73) 2)の赫告においても，唇似あ

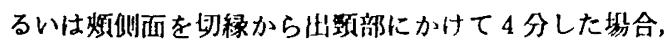
最掬影侧は增㱓的に一方的に增加する少向にあったが， それより一つ中央部寄りの部分でのフッ热搌度は一待增 加後高年龄では娍少するという変化を示していた。

今回の实駼における落影部は Weatherell のこの药冠 中央部に近いうの海垔倒の変化と大変良く似た結果を得 た。

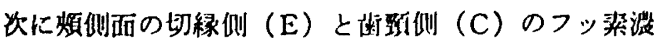

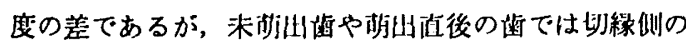

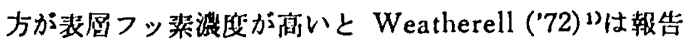

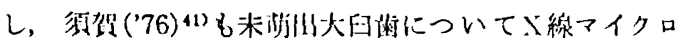

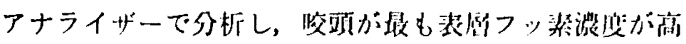

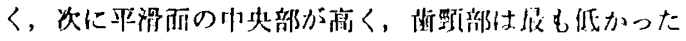
ことを瑟めている。

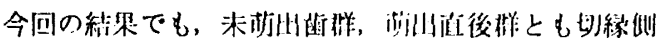

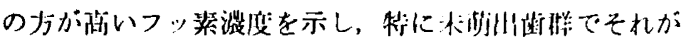
频著であった。

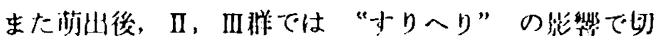
緑仙の方が低いフッ染泿諓を示したこともこれ迄の

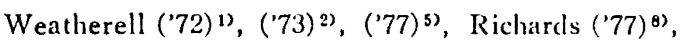
('79) ${ }^{9)}$, Koulourides ('79) ${ }^{10)}$ 算の教皆と一致した。

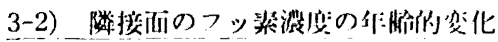

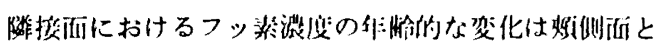

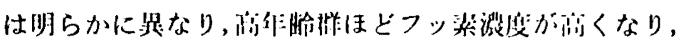
そ扎らの相阙係数も近心洏で $\mathrm{r}=0.597$, 迎心们で $\mathrm{r}=$

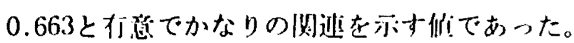

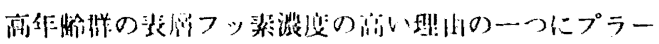

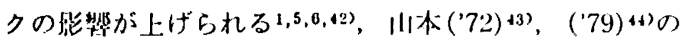

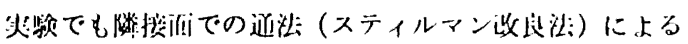

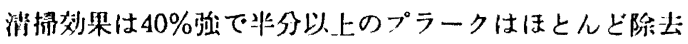
されないままにある。

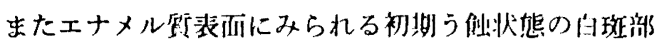

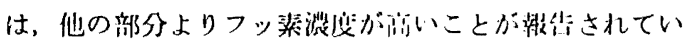
る(5,46)。

今回のサンプルでは第IV碚に卓玟が羿められたが，こ

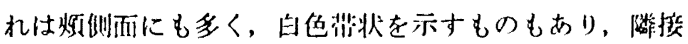
而に限ら机るものではなかった。しかも佂料採忟川のウ

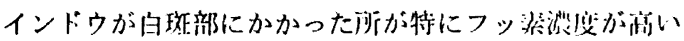
という倾们はなかった。

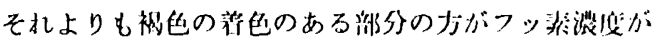
高くなるように思われた。これは Little ('62) ${ }^{34) の ェ ナ ~}$

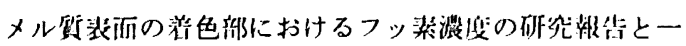
致する。

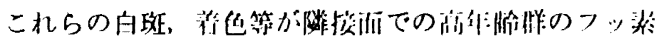

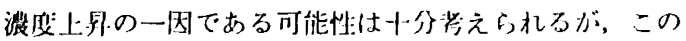

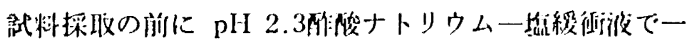

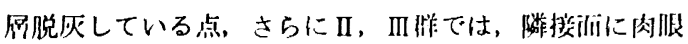

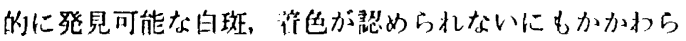

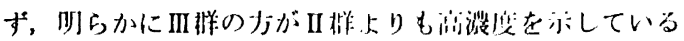
ことから、プラークの存任によるフッ类の㣼り込みが大 きな因子であることが推洲された。

つまり隣接䢹では湖山後“寸りへり”は生じる可能

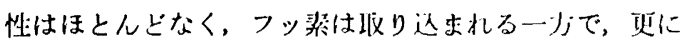

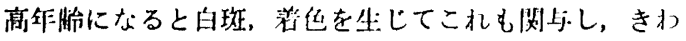


めて高いフッ柬溜度を示したものと思われる。

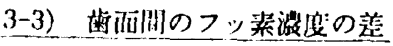

以上の形胃から，当然，各作愉棑に执いて歯西間にフ

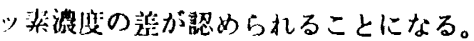

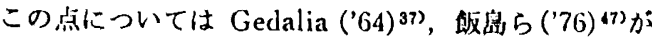

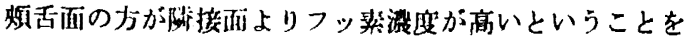
報告している。しかし，耐者では䑻盉について，後者に

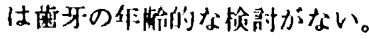

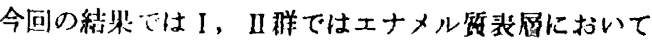

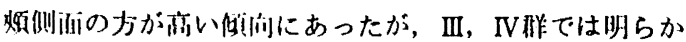

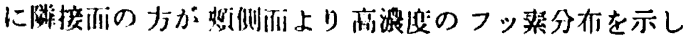
た。

このことと同じ絬果を報告した吥究は少ないが，

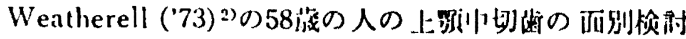
の利: ‘'

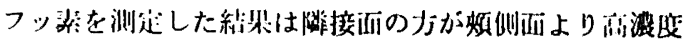
の低を示している。

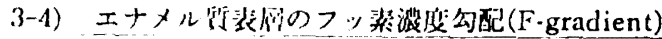

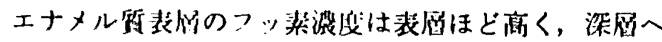
行くにつ机減少するという知見が一般的であるが31-84)，

“ナりへリ”の止ずる部位では逆に表首の力が少なく， 梁局へ行くにつれ增扠するという報告が Weatherell ('72) $)^{1)},\left({ }^{2} 73\right)^{2)},\left({ }^{2} 77\right)^{5)}$ Jones ('78)门によってなさ

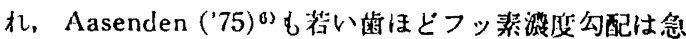
であるとし，仕坽に伴う“すりへり”の影惩を認めて いる。

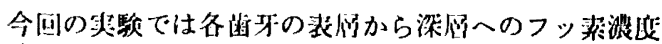

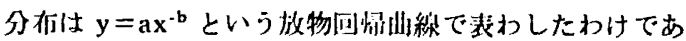

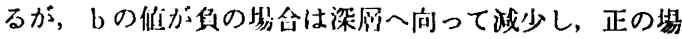
合は逆に增加するということになる。

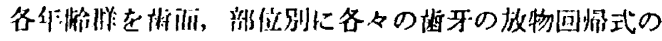
bの倠の正矣の状他を示したのが Table 4 である。

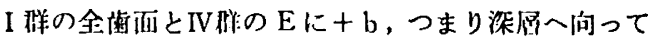

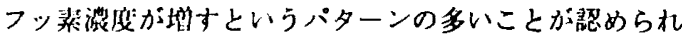
る。

Table 4 Distribtion of the pattern of F-gradient in age groups and surface regions

\begin{tabular}{c|c|c|c|c|r}
\hline & I & II & III & IV \\
\hline $\mathrm{M}$ & $-/+$ & $3 / 7$ & $8 / 2$ & $9 / 1$ & $10 / 0$ \\
$\mathrm{E}$ & $-/+$ & $0 / 10$ & $7 / 2$ & $7 / 2$ & $3 / 7$ \\
$\mathrm{C}$ & $-/+$ & $4 / 6$ & $8 / 0$ & $7 / 2$ & $7 / 3$ \\
$\mathrm{D}$ & $-/+$ & $2 / 8$ & $9 / 0$ & $9 / 1$ & $10 / 0$
\end{tabular}

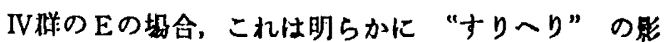
致の表わ机と思われるが，肉服的にきわめて強い“十り ヘり”の惩められる部位を武料探取した 2 通のbは負の

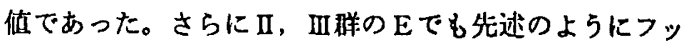
素洤度の娍少が明らかであるのに一bのものが多くフッ 来滥俀公配の这耺がられなかった。

これは本実雅において速繶 4 層サンブリングして得た 值に $\mathrm{y}=\mathrm{ax}^{-b}$ の式を近似させるといら娼作を行らため, たとえ第一屡が低い值でも次の 3 つの屏の值の状況から bの做が負となってしまうことが於算上生してしまうた めと思わ机る。

次に“すりへり”の全く生し得ない未消出歯样 (I)で b の值の正となるものがきわめて多かった。

この埸合考えられることは测定に用いた都牙が菏出前 でフッ装収り込みの途中の状热であったこと。また陚料 探取洔点で漏洩 (side etching) の生した可能性, さら に今回の然䮦方法で最初にエナメル领溶船性测定のため

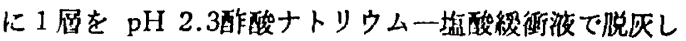
たことの影響である。

Side etching が特にI群にのみ系統的に生したとは 考えにくく，また内眼的顊察においても試料探取後の脱 灰西が歪んで広くなっているということもなかった。

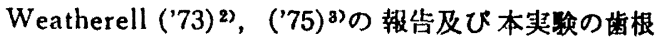

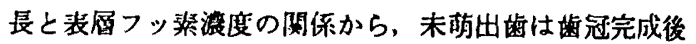
杖帅までの䦌にフッ素を取り込むことは明らかである。

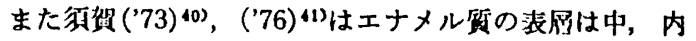
甬に比べ恨も取後に石灰化を終えると報告している。こ

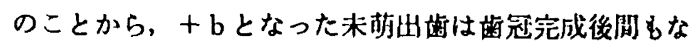
く，荡山朔の表局のフッ猆の取り込みが少い特期にあっ たために gradient が深屌へ向って㘿すという形になっ たことが考えられる。

しかし, Weatherell ('73) 2)，('75) 5)のヒト末荫此歯 や们物实呀, Brudevold ('56) ${ }^{30)}$ ，須贺('76)(1)の七ト末

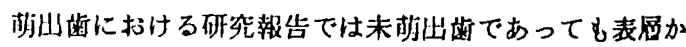
ら深居へフッ来湛度は減少している。

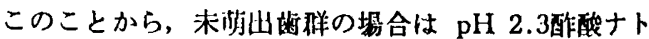

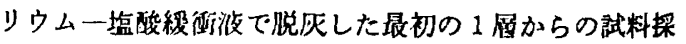

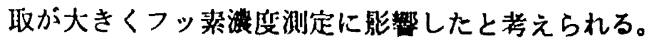

エナメル所溶解性については次の項で㭘討するが，と

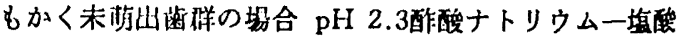
緩衍洨での脱灰照は他の萠出菌群の倍以上であった。

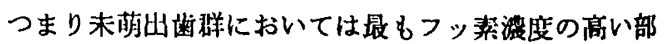
分を取ってしまった後の部分を测定した可能性が强く， 丁度 Weatherell ('77)"の：ナりへり”の人工実歌と 
大变良く似た結果となった。

以上の未萌出歯のエナメル所表征フッ素淡度について は，今後さらにその测定方法も含めて検畋が必要と思わ れる。

\section{4. エナメル倎溶解性}

\section{4-1) 年龄的変化}

ナへてての歯面，部位において未萠出菌椎（I）の方が 有意に萌出藏群（II，III，IV）上りも溶解性が高いとい ら結果が得られた。

この未萌出齒と萌出菌间のエナメル斦溶解性の差の検 討には、リンの溶出量を Index としてみた Brudevold

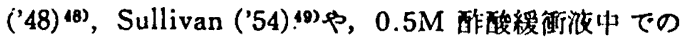
エナメル啠の Weight-loss を Index とした Isace ('58) ${ }^{50)}$ さらには0.1M 過场素酸を作間させ，溶汕カル シウム盟をみた小估野 ('75) ${ }^{21)}$ ，そして今回と闹棁の $\mathrm{pH}$ 2.3酢酸ナトリウム一垛酸緩衙没を用いた中垣 ('79) ${ }^{13}$ ら の報告がある。

これらのすべての報告は，未萌出藏の方が梛出齿より も溶解性の高い颉向にあることを認めているが，脱灰溶 液の問題, 菊種の不統一等のサンプル上の問題から統計 的に明らかな差は得られなかった。

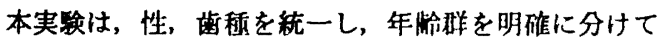
実験したためか，危険蒜 1 〜 0.1\%で末萌出齿群の方が 有意に高いエナメル倎溶解性を示した。

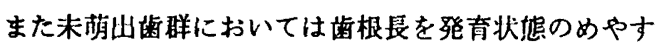
とし，それとエナメル犋溶解性の関倸についてみると， 明らかに根辰の長いものほどェナメル浣溶解性が低い值 を示す殒向にあり，Mでは $\mathrm{r}=-0.607$ という有意な㑯 の相関が珰められた。

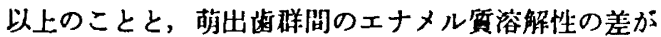
ほとんどないことから，エナメル啠溶解性は菏出前後の

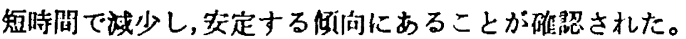

Brudevold ('48) ${ }^{48}$ はエナメル所溶解性は增龄的に娍

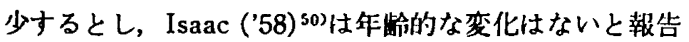
した。Cutress ('72) ${ }^{51)}$ も $\mathrm{pH}$ 4.5の乳酸綏衝液中への力 ルシウム溶出盘を Index とし10～66歳の小臼菌と犬蔽， 大曰歯について検郡した結果年制的なエナメル留溶解性 の変化はないとしている。

今回の実玡結果においても II 群, III群, IV群間の美は ナべての菌面, 部位において明らかでなかった。

しかし，各年舲群の测定値のバラッキに注目してみる と， $\mathrm{M} \cdot \mathrm{D}$ の隣接面は第IV群でバラッキが增し，煩侧面 (E・C) では，切緣侧でIV群がわずかに增しているが， 菊垔侧では逆に減少するといらように菌面，部位により
作昤的な変化に差のあることが羿められた。

つまり隣接而においては，荫出後高作踰になるほどェ ナメル質溶解性の個休差が增し，それに比べ媔似何はそ

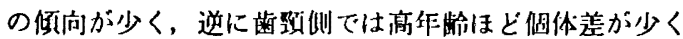
なっていくことが考えられる。

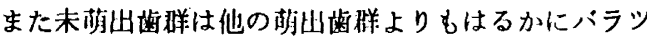
キが小さく、こ机はすべての将面，部位に漶められるこ

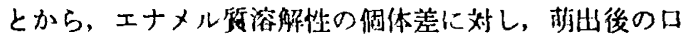

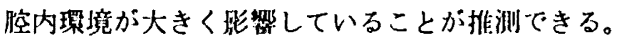

\section{4-2）齿面，部位阔のエナメル领溶解性:の差}

以上のようにエナメル颉溶解性の测定拨のバラッキに

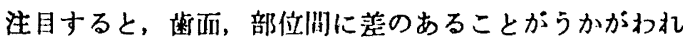
るが，この歯面，部位間のエナメル犋溶解性の美につい

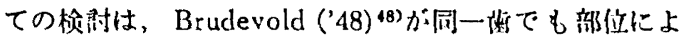

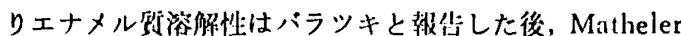
ら('60) ${ }^{52}$, Von der Fehr ら ('66) ${ }^{532}$ とり堭ら ('79) ${ }^{10) の ~}$ 行ったものしかない。

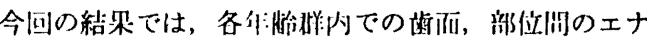

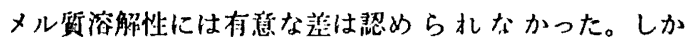

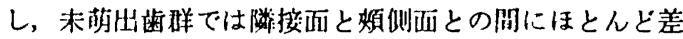
がないのに，萌出すると，エナメル梊溶解性は隣挼面の 方が低くなるという傾向があった。

このように枯出立にはは明らかでなかったエナメル整溶

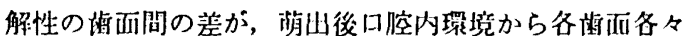
別々の影愬を受けて変化していくことが十分推测できた ことは興味深かった。

これらの変化に大きな影嘿を与をると思われるエナメ

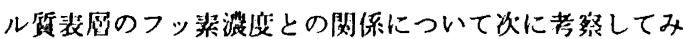
る。

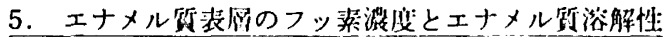
の関係

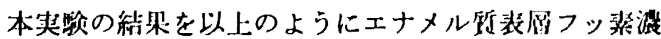
度とエナメル顿溶解性各々について梌行してみると，そ の各々の歯河・部位别の作秢的変化から，エナメル锤表

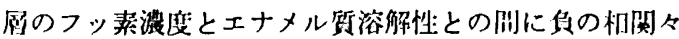
係のあることが十分排测できる。この点については， Isaac ('58) ${ }^{50)}$, Jenkins $(' 67)^{54)}$, Cutress $(' 72)^{51)}$, 饭

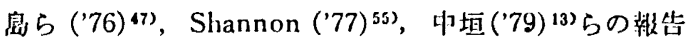
がある。

今回用いた歯牙のエナメル質溶解性とエナメル锤裴的

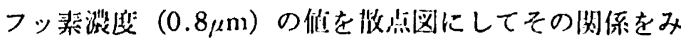

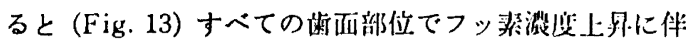
らエナメル矮溶解性の堿少倾问がみられた。しかし，筷

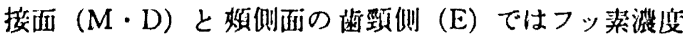


Table 5 Probabilites of missclasifcation

\begin{tabular}{|c|c|c|c|c|c|c|c|c|c|c|c|}
\hline & \multicolumn{4}{|c|}{$\begin{array}{c}\mathrm{M} \\
\text { follow-up sample }\end{array}$} & & & \multicolumn{4}{|c|}{$\begin{array}{c}E \\
\text { follow-up sample }\end{array}$} \\
\hline & & 1 & 2 & 3 & 4 & & & 1 & 2 & 3 & 4 \\
\hline$\frac{0}{0}$ & I & 8 & 2 & () & 0 & $\stackrel{\Delta}{a}$ & I & 9 & 0 & 0 & 1 \\
\hline 5 & II & 0 & 6 & 3 & 0 & E్ & II & 1 & 2 & 3 & 4 \\
\hline$\underset{u}{x}$ & III & 0 & 3 & 7 & 0 & $x$ & III & 0 & 3 & 3 & 3 \\
\hline$\underset{.}{.}$ & IV & 1 & 1 & 1 & 7 & $\Xi$ & IV & 2 & 0 & 4 & 4 \\
\hline
\end{tabular}

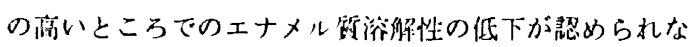
かった。

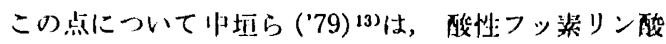

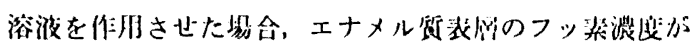
$3,000 \sim 4,000 \mathrm{ppm}$ 以上のところでフッ热沙度上㤢に伴

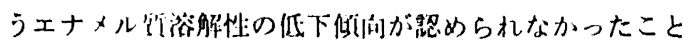

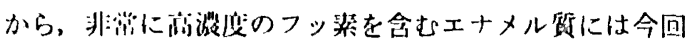

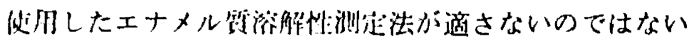
かと落察している。

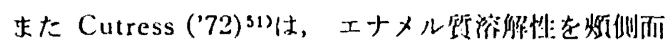

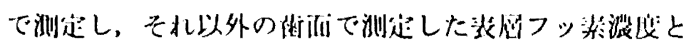
の相閔々倸を検討し，有望な貝の相関を得ているが，裴

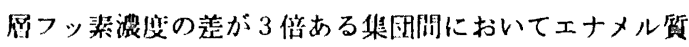

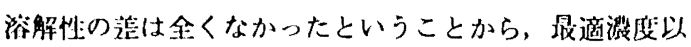

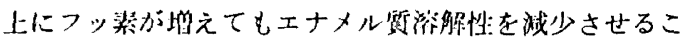
とはないのではないかと排测している。

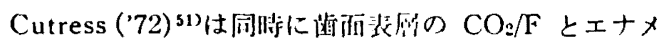

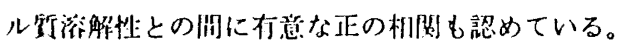

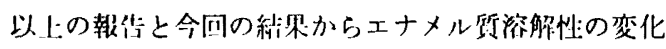

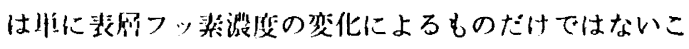
とが推测できる。

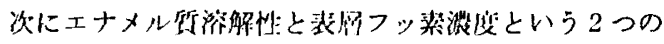

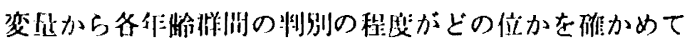
みた。垶算は Olivetti P6060統部分析シリーズの多変

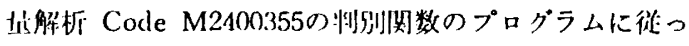
た。

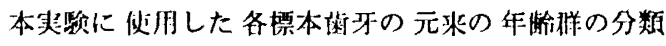
と，判别閂数から判别して分類した結果との哭分類の標 來泡率を Table 5 に示した。

その結果，エナメル貿非倠フッ素搌度とエナメル斦溶

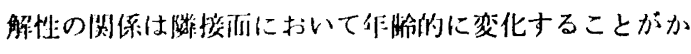
なりはっきり瑟められるが，煩侧佰での年柃的変化は明 碓でないことが考繁さ机た。

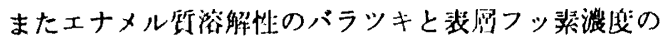
バラッキについて,その作䀫的な変化を比校梌討寸ると，

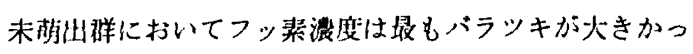

\begin{tabular}{|c|c|c|c|c|c|c|c|c|c|c|c|}
\hline & \multicolumn{4}{|c|}{$\begin{array}{c}\mathrm{C} \\
\text { follow-up sample }\end{array}$} & & & \multicolumn{4}{|c|}{$\begin{array}{c}\mathrm{D} \\
\text { follow-up sample }\end{array}$} \\
\hline & & 1 & 2 & 3 & 4 & & & 1 & 2 & 3 & 4 \\
\hline \multirow{4}{*}{ 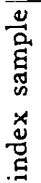 } & I & 8 & 0 & 0 & 2 & \multirow{4}{*}{ 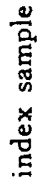 } & I & 8 & 2 & 0 & 0 \\
\hline & II & 0 & 4 & 1 & 3 & & II & 0 & 6 & 2 & 0 \\
\hline & III & 1 & 1 & 4 & 3 & & III & 0 & 5 & 3 & 2 \\
\hline & IV & 1 & 3 & 1 & 5 & & IV & 0 & 1 & 4 & 5 \\
\hline
\end{tabular}

たのに対し，エナメル颌济解性は逆に银もバラッキが小 さかった。またフッ絜浱度のバラッキはIII，IV群と高年 牊棚になるにしたがい颀仙面のバラッキが大きくなって 行く傾向があったのに対し，エナメル澌浴解性はこれも 近に隣挨而の方がバラッキが大きくなっていく倾向にあ った。

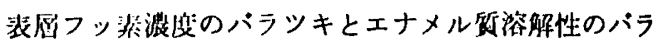
ツキ，及びその作跲的变化はう叫感受性の㑑体差䁢別に 重要な手がかりとなると想わ机るが、これらについての

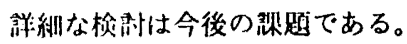

\section{まとめ}

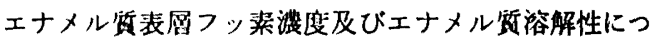
いて，未だ头証の少ない歯面，部位別の検璟，及びそれ

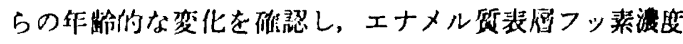

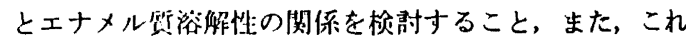
らを行うために同一部位でェナメル频溶解性とフッ素浱 度を测定する方法を梌尉することを目的としてこの研然 を行った。

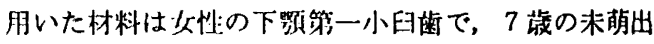

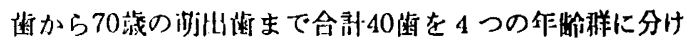

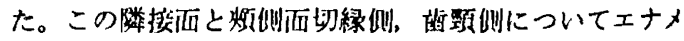

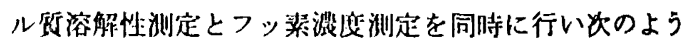
な綜果を得た。

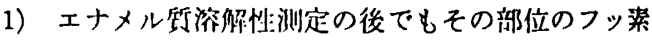
波纺を测证できた。

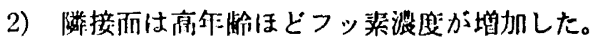

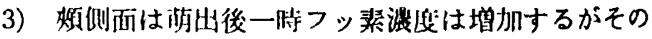
後娍少する俱向にあり，特に切粶侧での減少は早期に生 し，かつ，著しかった。

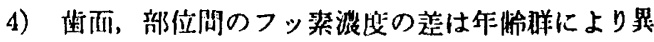

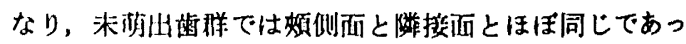

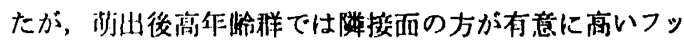
猆懐发を示した。

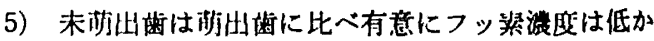

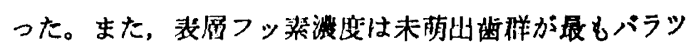


キが大きかった。

6）エナメル所溶解性は萌出前後の短期間に娍少した

後，安定する倐向にあった。

7）エナメル梊溶解性の歯面，部位による差は末萌出 歯群ではほとんど差はなかったが，明出後高年㱓群では 接面の方が煩侧面より低かった。

8）エナメル啠浴解性のバラッキは未枯出遴群が最も 小さく，明出後高年龄样ほどやや大きくなった。また一 般に隣接面の方が煩侧面より大きかった。

9）エナメル啠表屈フッ絭港度が高くなるとエナメル 段溶解性が诚少するという㒋向があった。

\section{甜辞}

䅻を終るにあたり，終始御指方扩よび御校間をいたた

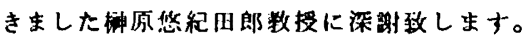

また御校阅をいただきました生化学教定早川太郎教 投そして御教示いただきました病理学教宝他川洋一教 投に暗意を芘します。

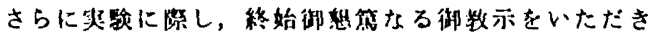

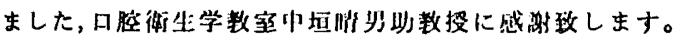
また御场力いただきました口腔衛生学教室各位に深愔政 します。

\section{女献}

1) Weatherell, J. A., Robinson, C. and Hallsworth, A. S.: Changes in the Fluoride Concentration of the Labial Enamel Surface with Ages, Caries Res. 6:312-324, 1972.

2) Weatherell, J. A., Hallsworth, A. S. and Robinson, C. : The Effect of Tooth wear on the distribution of Flupride in the Enamel Surface of Human Teeth, Archs oral Biol. 18 : 1175-1189, 1973.

3) Weatherell, J. A., Deutsch, D., Robinson, C. and Hallsworth, A. S. : Fluoride Concentrations in Developing Enamel, Nature. 256 : 230-232, 1975.

4) Weatherell, J. A., Naylor, G. and Hallsworth, A. S.: Measurement of Topical Fluoride Acquired by Sound Human Enamel, Caries Res. 11 : 231-236, 1977.

5) Weatherell, J. A., Deutsch, D., Robinson, C. and Hallsworth, A. S.: Assimilation of Fluoride by Enamel throughout the Life of the Tooth, Caries Res. 11 (Suppl. 1) : 85115, 1977.

6) Aasenden, R. : Post-Eruptive Changes in the Fluoride Concentrations of Human Tooth Surface Enamel, Archs oral Biol. 20 : 359-
$363,1975$.

7) Jones, K. W., Annegarn, H. J. and Sells. chop, J. P. F. : Charged Particle Analyses of Fluorine Distributions in the Surface of Human Tooth Enamel, Archs oral Biol. 23: 31-37, 1978.

8) Richards, A., Joost Larsen, M., Fejerskov, O. and Thylstrup, A.: Fluoride Content of Buccal Surface Enamel and its Relation to Dental Caries in Children, Archs oral Biol. 22 : 425-428, 1977.

9) Richards, A., Larsen, M. J. and Feierskov, O.: Fluoride Content of Buccal Surface Enamel from Caries-Free Mediaeval Subjects, Archs oral Biol. 24: 83-84, 1979.

10) Koulourides, N. and Walker, A. : Fluoride Distribution in the Facial Surfaces of Hu. man Maxiiary Central Incisors, Journal of Oral Pathology. $8:$ 179-18:3, 1979.

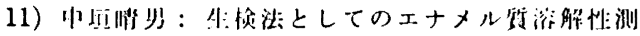

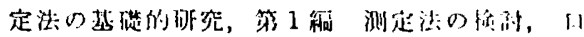
術誌, 28(4) : 464-497, 1979.

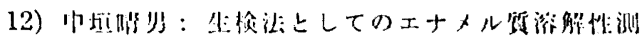

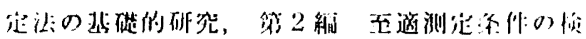
籿，口街悲，28(4) : 498-518，1979.

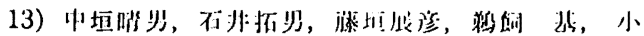

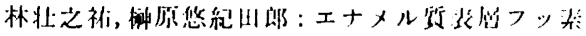

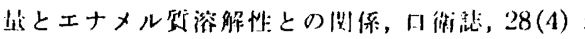
519-530, 1979.

14) Baijot-Stroobants and Vreven, J.: Determination by Charged Particles Activation of Fluoride Uptake in Human Dental Enamel, Caries Res. $13: 211-217,1979$.

15) Aasenden, R. : Fluoride Concentrations in the Surface Tooth Enamel of Young Men and Women, Archs Oral Biol. 19:697-701, 1974.

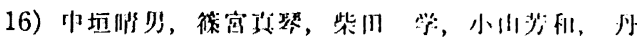

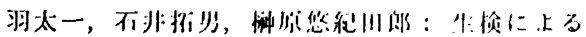

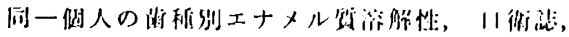
29 (1) : 25-38, 1979.

17) Mellberg, J. R. : Fluoride Uptake by Intact Human Tooth Enamel from Acidulated Filuoride-Phosphate Preparations, J.D.R. 45 : 303306, 1966.

18) McCann, H. G.: The Effect of Fluoride Complex Formation on Fluoride Uptake and Relation in Human Enamel, Archs oral Biol. $14: 521-531,1969$.

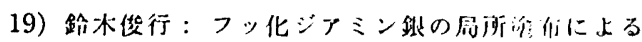

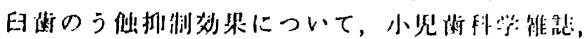
11 (1) : 33-54, 1973.

20) Richard, T. Koritzer, and John S. Levy: Enhanced Fluoride Penetration and Retention in Enamel, Caries Res. 13:259-264, 
1979.

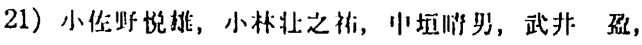

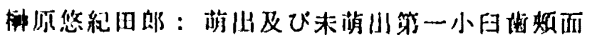

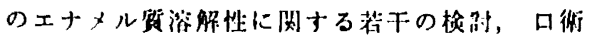
誌, 25(2) : 73-82, 1975.

22) Kirkegaard, E.: In vitro Fluoride Uptake in Human Dental Enamel from Various Fluoride Solutions, Caries Res. 11 : 16-23, 1977.

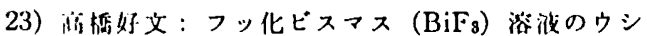

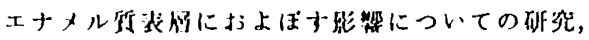

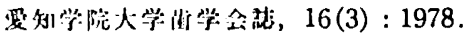

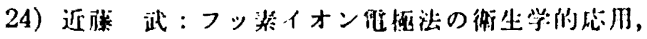

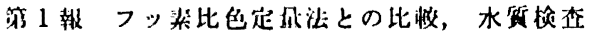

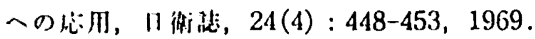

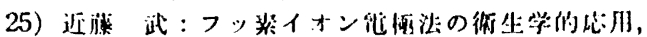

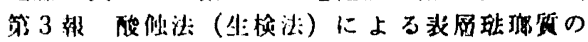

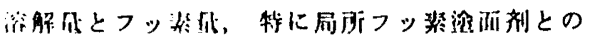

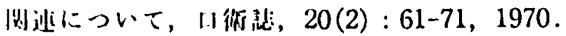

26) Rytömaa, I. and Keinonen, J. and Anttila, A. : Sensitive Physical Method for Deteamination of Fluorine Distribution in Human Surface Enamel, Archs. oral Biol. 19 : 553556, 1974.

27) Rajan, K. S., Raisen, Elliott., Mandler, John, W., Riley, Denis, L., and Semmler, Richard, A. : Improved Fluoride Incorporation and New in Vitro Fluorine Elemental Determination, J. Dent Res. 671-677, 1976.

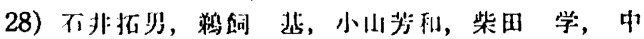

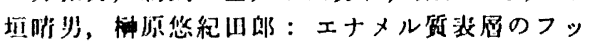
深低とエナメル犋淮解性の作䏩的变化に関する

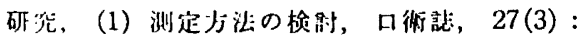
93, 1977.

29) Bischoff, J. I., van der Merwe, E. H. M., Retief, D, H., Barbakow, F. H. and CleatonJones, P. E. : Relationship between Fluoride Concentratuon in Enamel, DMFT Index, and Degree of Fluorosis in a Community Residing in an Area with A High Level of Fluoride, J. Dent Res. 55 : 37-42, 1976.

30) Richards, A., Fejerskov O. and Larsen $M$. J. : Distribution of Fluoride in Relation to Structual Changes of the Tissue, Caries Res. $1: 3: 118,1979$.

31) Brudevold, F., Gardner, D. H. and Smith, F. A.: The Distribution of Fluoride in Iluman Enamel, J. Dent Res. 35 : 420-429, 1956.

32) Isaac, S., Brudevold, F., Smith, F. A. and Gardner, D. H.: The Relation of Fluoride in the Drinking Water to the Distribution of Fluoride in Enamel, J. Dent Res. 37 : $318-325,1958$.

33) Yoon, S. H., Brudevold, F., Gardner, D.
E. and Smith, F. A. : Distribution of Fluoride in Teeth from Areas with Different Levels of Fluoride in the Water Supply, J. Dent Res. 39 : 845-856, 1960.

34) Gedalia, I., Rosenzweig, K. A. and Sadeh, A. : Fluorine Content of Superficial Enamel Layer and its Correlation with the Fluorine Content of Saliva, Tooth Age, and DMF'T Count, J. Dent Res. 40 : 865-869, 1961.

35) Little, M. F., Posen, J. and Singer, L. : Chemical and Physical Properties of Altered and Sound Enamel 3. Fluoride and Sodium Content, J. Dent Res. 41 : 784-789, 1962.

36) Armstrong, W. D. and Singer, L.: Fluoride Contents of Enamel of Sound and Carious Human Teeth: A Reinvestigation, J. Dent Res. 42 : 133-136, 1963.

37) Gedalia, I. and Kalderson, S. : Fluoride in the Surface Enamel of Teeth from the Same Mouth, J. Dent Res. 43 : 44-49, 1964.

38) Hargreaves, J. A. : Enamel Wear in Deciduous Teeth with Age, Related to Surface Fluoride Content, Caries Res. 1 : 32-41, 1967.

39) Speirs, R. L. : Fluoride Concentration in Tooth Germs of Parmanent Teeth of the Domestic Pig, Archs oral Biol. 23 : 10191021, 1978.

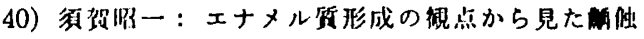
の発生と病変, 出海のシンボジウム病因踰, 䐠

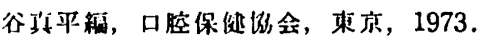

41）得驾沼一：エナメル梊形成の镍念から見たエナ

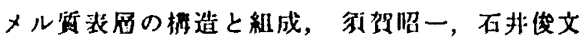

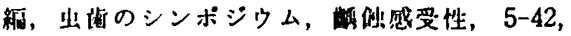

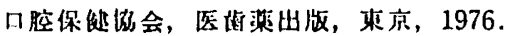

42) Bruun, C. and Stoltze, K. : In Vivo Uptake of Fluoride by Surface Enamel of Cleaned and Plaque-Covered Teeth, Scand. J. Dent Res. $84: 268-275,1976$.

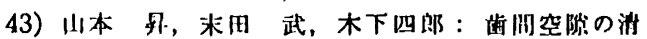
捅について，日本修周病学会会諔，14(2):4147, 1972.

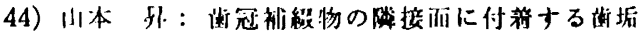

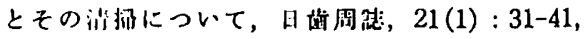
1979.

45）漓江洲矩，仮的洋一：エナメル梊装局に㧍け ろフッ癷とその反応䈋式，㑁感变性，エナメ

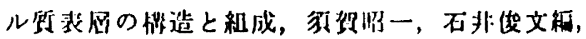
117-131，口腔保健访会，医海整山股，来方， 1976.

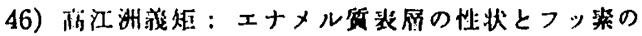

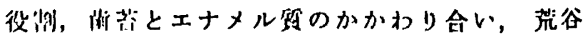

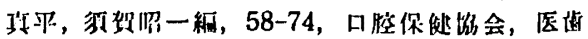
桨山版, 来底, 1978.

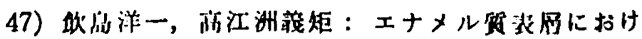




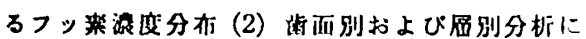
ついて，口街路，26(2):45-49，1976.

48) Brudevlod, F.: A Study of the Phosphate Solubility of the Human Enamel Surface, J. Dent Res. 27 : 320-329, 1948.

49) Sullivan, H. R. : The Solubility of Enamel Surfaces, J. Dent Res. 33 : 504-510, 1954.

50) Isaac, S., Brudevold, F., Smith, F. A. and Gardner, D. E. : Solubility Rate and Natural Fluoride Content of Surface and Subsurface Enamel, J. Dent Res. 37 : 254-263, 1958.

51) Cutress, T. W. : The Inorganic Composition and Solubility of Dental Enamel from Se. veral Specifield Population Groups, Archs oral Biol. 17 : 93-109, 1972.

52) Marthaler, T. M. and Zilio, R. : Enamel
Solubility Studies in Vivo: Method, Error and Effect of Topically Applied Fluorides, Helv. Odont. Acta, 4:27-33, 1960.

53) von der Fehr F. R. \& Steinnes F.: The Solubility Rate of Unabrabed and Exposed Human Surface Studies by Means of Activation Analysis, Archs oral Biol. 11 : 14051418, 1966.

54) Jenkins, G. N. : The Mechanism of Action of Fluoride in Reducing Caries Incidence, International Dental Journal. $17: 552-563$, 1967.

55) Shannon, I. L. and Trodahl, J. N. : Effect of Waterborne Fluoride Concentration and Solubility of Dental Enamel, Australian Dental Journal. $22: 428-431,1977$.

Abstract: Regional and Age-related Variations in Solubility and Fluoride Concentraion on the Surface of Human Tooth Enamel, Takuo ISHII*. The purpose of this study was to examine the regional and age-related variations in the enamel solubility and the fluoride concentration on the surface of women's lower first premolars and to develop a technique to determine both enamel solubility and fluoride concentration using dissolved enamel from the same point on the tooth surface.

The following results were obtained.

1) Both the enamel solubility and the fluoride concentration could to be determined at the same window of enamel (3-mm diameter) on tooth surface.

2) Fluoride concentration on the approximal surfaces were higher in older persons than in younger persons. The fluoride concentrations on the buccal surface increased transiently after eruption and then decreased. The decrease of fluoride concentration appeared to be most remarkable near the biting edge of the buccal surface in earlier stage.

3) The differences in the fluoride concentrations between the approximal surfaces and the buccal surface in the group of unerupted teeth were not significant, but in the older group the approximal surface showed significantly higher fluoride concentrations than the buccal surface.

4) The gourp of unerupted teeth showed significantly lower fluoride concentrations than the.group of erupted teeth, and the most scattered value of all.

5) Enamel solubility tended to decrease first and then to drop to a plateau shortly alter eruption.

6) There were no differences in the enamel solubility between the approximal surfaces and the buccal susface, but in the older group the approximal surface. showed lower enamel solubility than the buccal surface.

7) The group of unerupted teeth showed the least scattered values of all in the enamel solubility. The enamel solubility of the approximal surfaces tended to be more dispersed than that of the buccal surface.

8) There was a reverse relationship between fluoride concentration and enamel solubility. 